\author{
KATARZYNA WOJAN \\ Instytut Filologii Wschodniosłowiańskiej Uniwersytetu Gdańskiego \\ ul. Wita Stwosza 55, 80-952 Gdańsk \\ Polska - Poland
}

\title{
Z POLSKO-ŁACIŃSKIEJ LEKSYKOGRAFII PRZEKŁADOWEJ. CZ. II. BIBLIOGRAFIA SŁOWNIKÓW Z JĘZYKIEM ŁACIŃSKIM ZA LATA 1990-2011 W UKŁADZIE CHRONOLOGICZNYM*
}

\begin{abstract}
Wojan Katarzyna, Z polsko-łacińskiej leksykografii przekładowej. Cz. II. Bibliografia słowników z językiem łacińskim za lata 1990-2011 w układzie chronologicznym (From Polish translation lexicography. Part II. Bibliography of dictionaries with Latin language, years 1990-2011, in chronological order).

The article contains a list of 405 lexicographical items (each including Latin language), published in Poland during the years 1990-2011. The bibliography, composed in chronological order. The material in question has been excerpted and catalogued on the basis of bibliographical sources, scientific publications, publishing and library catalogues, available at the time. The fact that so much bibliographical material has been collected proves that for publishers, Latin is still a prestigious language, which enjoys a high scientific and academic status. The bibliography exemplifies editorial dynamics and welcoming attitude towards Latin language on the part of national publishers and scientific centers.
\end{abstract}

Keywords: Latin language, bilingual and multilingual lexicography, philological, terminological and encyclopedic dictionaries, bibliography.

Zamieszczony poniżej zbiór pozycji bibliograficznych jest kontynuacją próby zindeksowania współczesnych polskich słowników z językiem łacińskim. Wykaz publikacji, zawarty w niniejszym artykule, to rejestr współczesnych polsko-łacińskich i łacińsko-polskich prac leksykograficznych, wydanych w Polsce, a także w koedycji z zagranicznymi wydawcami w latach 1990-2011. Ujęto także, podobnie jak w dotychczasowych zestawieniach, zagraniczne prace słownikarskie autorstwa polskich uczonych oraz polskie adaptacje leksykograficzne publikacji zagranicznych. Nadrzędnym celem niniejszego zbioru jest ukazanie w możliwie pełnym zakresie bogactwa współczesnych polskich publikacji słownikarskich z hasłami łacińskimi. Pojęcie słownik w przedkładanej pracy oznacza „zbiór uporządkowany materiału leksykograficznego”", w związku

*Cz. I. Bibliografia słowników z językiem łacińskim za lata 1964-1989 w układzie chronologicznym jest zamieszczona w „Symbolae Philologorum Posnaniensium” 2013, XXIII/1.

${ }^{1}$ Definicja za: P. Grzegorczyk, Index lexicorum Poloniae. Bibliografia słowników polskich, Warszawa 1967, s. 10. 
z czym niniejszy przegląd obejmuje typologicznie zróżnicowane opracowania słownikarskie: od lingwistycznych po encyklopedyczne. Należy dodać, iż w niniejszym wykazie termin leksykon występuje jako synonim terminu słownik. Trzon opracowanego wykazu bibliograficznego stanowią pozycje leksykograficzne o charakterze przekładowym, tj. dwujęzyczne i wielojęzyczne słowniki filologiczne, terminologiczne, encyklopedyczne i dokumentacyjne. Włączono do niego nie tylko dzieła samodzielne, ale też opracowania niesamodzielne, objętościowo mniejsze, będące dodatkiem do innych. Wzorem lat ubiegłych spisem objęto opracowania zawierające znaczące, obszerne indeksy terminów dziedzinowych, posiadające łacińskie odpowiedniki przekładowe (bądź polskojęzyczne w przypadku hasła łacińskojęzycznego), glosariusze, nomenklatory, przekładowe atlasy anatomiczne, wykazy łacińskich słów i form dołączone do dzieł literackich, leksykograficzne uzupełnienia, indeksy a tergo, zbiory siglów i skrótów wraz z tłumaczeniami, a także antologie łacińskich paremii i cytatów. Ponadto wykaz gromadzi naukowe słowniki jednojęzyczne, wokabularze, mamotrekty i glosy do tekstów rękopisów i inkabułów, komentarze filologiczne i objaśnienia leksykalne do znaczących prac literackich i biblijno-teologicznych. Scharakteryzowany powyżej zestaw dzieł leksykograficznych o zastosowaniu typowo translatorskim został wzbogacony o ważkie dla polsko-łacińskiej leksykografii historycznej pozycje stanowiące przedruki dawnych dzieł, dygitalizacje, modyfikacje i naukowe uzupełnienia tych dzieł. W wykazie pominięto słowniczki on line publikowane w ogólnodostępnych portalach internetowych, a także słowniczki przylekcyjne podręczników do nauki języka łacińskiego; uwzględniono jedynie podręcznikowe słowniki translatoryczne z obszerną siatką hasłową. Spośród opracowań encyklopedycznych z zakresu nauk przyrodniczych, w których hasłom polskim towarzyszą łacińskojęzyczne nazwy systematyczne, wyselekcjonowano znaczącą liczbę pozycji; należy jednak podkreślić, iż rzeletna analiza wszystkich publikacji tego typu z uwagi na ich mnogość i znaczne rozproszenie w sieci bibliotek - jest w dniu dzisiejszym technicznie niemożliwa do przeprowadzenia. Listą niniejszą nie objęto słowników etymologicznych ani słowników wyrazów obcych. Dodatkowo zbiór wzbogacono o wybrane pozycje encyklopedyczne (głównie biograficzne) i dokumentacyjne (spisy, wykazy etc.) z hasłami łacińskimi.

Szerokie spektrum tematyki i charakteru merytorycznego zaprezentowanych publikacji słownikowych, ujętych we wspólnym zestawieniu, z jednej strony stanowi swoiste kompendium informacji na temat dorobku słownikarzy polskich, zgłębiających bogatą i rozległą przestrzeń kultury języka łacińskiego, z drugiej strony $w$ intencji autorki winno stanowić formę pewnego rodzaju uhonorowania ich pracy. Przyjęty w niniejszej bibliografii podział chronologiczny umożliwia bardziej przejrzysty wgląd w obecny stan polskiego słownikarstwa.

Materiał bibliograficzny został wyekscerpowany i skatalogowany na podstawie dostępnych źródeł bibliograficznych, publikacji naukowych, katalogów 
bibliotecznych i wydawniczych. Przygotowując niniejszą bibliografię do publikacji, zastosowano następujące zasady redakcyjne:

W procesie konfigurowania wykazu zachowano porządek chronologiczny, co oznacza, iż pozycje słownikarskie pogrupowano w działach według roku ich wydania. W poszczególnych działach pozycje słownikarskie uszeregowano według nazwisk autorów (ew. redaktorów), a w przypadku opracowań zbiorowych według tytułów - w obu przypadkach zgodnie z kolejnością liter alfabetu polskiego. $\mathrm{W}$ przypadku pozycji sygnowanych nazwiskiem autora po nazwisku umieszczono jego pełne imię (imiona), o ile występuje ono (występują one) w pełnej formie na stronie tytułowej dzieła. W odniesieniu do prac zbiorowych imię redaktora (redaktorów) i autorów haseł umieszczono przed nazwiskiem. W miejscu opisu bibliograficznego zamieszczono akronim nazwy wydawcy, instytucji wydawniczej lub jej oddziału. Jeśli nazwa wydawcy (instytucji wydawniczej) pojawia się w wykazie tylko raz, przytacza się ją w pełnym brzmieniu. W przypadku braku nazwy wydawcy podano nazwę dystrybutora. Jeżeli pozycja wydawnicza nie zawiera daty wydania, to podano rok copyright, poprzedzony skrótem cop. W adresie bibliograficznym uwzględniono również kolejność wydania, nazwę serii i - każdorazowo - liczbę stron ( $\mathrm{z}$ wyjątkiem publikacji w formie elektronicznej).

WYKAZ POLSKICH OPRACOWAŃ LEKSYKOGRAFICZNYCH Z JĘZYKIEM ŁACIŃSKIM: FILOLOGICZNYCH, TERMINOLOGICZNYCH I ENCYKLOPEDYCZNYCH, WYDANYCH W LATACH 1990-2011

\section{0}

1. Burakowski Bolesław, Mroczkowski Maciej, Stefańska Janina, Chrzaszcze = Coleoptera: Stonkowate-Chrysomelidae, cz. 1, Inst. Zoologiczny PAN, Katalog Fauny Polski = Catalogus Faunae Poloniae, cz. 23, t. 16, PWN, Warszawa 1990, ss. 279 [Zawiera Indeks nazw systematycznych w jęz. łac.].

2. Czyżma Jolanta, Roguszczak Elżbieta, Język łaciński. Podręcznik dla lektoratów uniwersyteckich, [wyd. 1], Wyd. UG, Gdańsk 1990, ss. 182 [Zawiera Słowniczek łacińsko-polski, Słownik polsko-łaciński].

3. Dąbrowska Barbara, Słownik medyczny łacińsko-polski = Vocabularium medicum Latino-Polonum, PZWL, Warszawa 1990, ss. X, 724.

4. Dąbrowska Barbara, Słownik medyczny polsko-łaciński = Vocabularium medicum Polono-Latinum, PZWL, Warszawa 1990, ss. VI, 903.

5. Jędraszko Czesław, Łacina na co dzień, oprac. graf. Andrzej Strumiłło, wyd. 8, Nasza Księgarnia, Warszawa 1990, ss. 331, [5] [Zawiera słownik].

6. Ptaki, t. 1, red. Przemysław Busse, [noty encyklopedyczne napisali Przemysław Busse et al., rys. Tomasz Cofta et al.], Mały słownik zool., Wiedza Powszechna, Warszawa 1990, ss. 402, [48] [Tekst częśc. łac.]. 
7. Słownik łacińsko-polski wedtug słownika Hermana Mengego i Henryka Kopii, oprac. Kazimierz Kumaniecki, wyd. 18, PWN, Warszawa 1990, ss. VIII, 545, [7].

8. Wilczyński Stanisław, Zarych Teresa, Lectio latina dla klasy II liceum ogólnokształcacego. Cz. 1: Czytanki łacińskie, cantiunculae, czytanki polskie, słowniczek łacińsko-polski, wyd. 5, WSiP, Warszawa 1990, ss. 111, [1].

9. Wilczyński Stanisław, Zarych Teresa, Lectio latina dla klasy III liceum ogólnoksztatcacego. Cz. 1: Czytanki łacińskie, acute dicta, cantiunculae, czytanki polskie, stowniczek tacińsko-polski, wyd. 4, WSiP, Warszawa 1990, ss. 119, [1].

10. Wilczyński Stanisław, Zarych Teresa, Lectio latina dla klasy IV liceum ogólnokształcącego. Cz. 1: Czytanki łacińskie, cantiunculae, czytanki polskie, słowniczek łacińsko-polski, wyd. 4, WSiP, Warszawa 1990, ss. 135, [1].

11. Wilczyński Stanisław, Zarych Teresa, Rudimenta linguae latinae, Cz. 1: Teksty i słownik, wyd. 3, Wyd. UWr, Wrocław 1990, ss. 140.

12. Wykaz zwierząt Polski, t. 1, Cz. 32/1-20, Insecta: Protura - Planipennia = Checklist of animals of Poland, vol. 1, Pt. 32/1-20, red. Józef Razowski, [aut. Władysław Bazyluk et al.], Inst. Systematyki i Ewolucji Zwierząt PAN, Kraków 1990, ss. 158 [Tekst pol., łac., ang.].

\section{1}

13. Baranowski Marian, Jankowski Marek, Słownik rybacki angielsko-polski i polsko-angielski z glosariuszem łacińskich nazw ryb, Pol. Tow. TEPIS Unitranslex, Warszawa 1991, ss. 132.

14. Burakowski Bolesław, Mroczkowski Maciej, Stefańska Janina, Chrzaszcze = Coleoptera: Stonkowate-Chrysomelidae, Cz. 2, Inst. Zoologiczny PAN, Katalog Fauny Polski = Catalogus Faunae Poloniae, cz. 23, t. 17, PWN, Warszawa 1991, ss. 226, [1] [Zawiera Indeks nazw systematycznych w jęz. tac.].

15. Feneis Heinz, Ilustrowany słownik międzynarodowego mianownictwa anatomicznego, z niem. przeł. Renata Modrewska-Winowska i Jerzy Winowski, wyd. 3, PZWL, Warszawa 1991, ss. X, [2], 567, [1].

16. Jurewicz Oktawiusz, Winniczuk Lidia, Żuławska Janina, Język łaciński. Podręcznik dla lektoratów szkót wyższych 1, wyd. 14 zm. i rozsz., PWN, Warszawa 1991, ss. 263, [1] [Zawiera Stownik i skorowidz gramatyczny (tj. Słownik łacińsko-polski, Słownik imion własnych, Słownik terminów gramatycznych)].

17. Jurewicz Oktawiusz, Winniczuk Lidia, Żuławska Janina, Język łaciński. Podręcznik dla lektoratów szkót wyższych 2, wyd. 14 zm. i rozsz., PWN, 
Warszawa 1991, ss. [5], 263-645, [2] [Zawiera Stownik i skorowidz gramatyczny (tj. Stownik tacińsko-polski, Słownik imion własnych, Stownik terminów gramatycznych)].

18. Karwowska Krystyna, Podręczny słownik lekarski tacińsko-polski i polsko--taciński, wyd. 4 popr. i uzup., PZWL, Warszawa 1991, ss. 478.

19. Przystowia i cytaty łacińskie, [zebr. Ryszard Ruszel], Wyd. Pagina, Gliwice 1991, ss. 22, [2].

20. Ptaki, t. 2, red. Przemysław Busse, [noty encyklopedyczne napisali Przemysław Busse et al., rys. Tomasz Cofta et al.], Mały słownik zool., Wiedza Powszechna, Warszawa 1991, ss. 399, [48] [Tekst częśc. łac.].

21. Wykaz zwierzat Polski, t. 2, Cz. 32/25-29, Insecta: Trichoptera - Siphonaptera; $\mathrm{pt}$ Chaetognatha - Mammalia $=$ Checklist of animals of Poland, vol. 2, Pt. 32/25-29, red. Józef Razowski, [aut. Zygmunt Bocheński et al.], Inst. Systematyki i Ewolucji Zwierząt PAN, ZNO, Kraków 1991, ss. 342 [Tekst pol., łac., ang.].

22. Wykaz zwierzat Polski, t. 3, Cz. 32/33, 23. Insecta: Coleoptera, Strepsipte$r a=$ Checklist of animals of Poland, vol. 3, Pt. 32/22, 23. Insecta: Coleoptera, Strepsiptera, red. Józef Razowski, [aut. Maciej Mroczkowski, Janina Stefańska et al.], Inst. Systematyki i Ewolucji Zwierząt PAN, ZNO, Kraków 1991, ss. 217 [Tekst pol., łac., ang.].

\section{2}

23. Burakowski Bolesław, Mroczkowski Maciej, Stefańska Janina, Chrząszcze = Coleoptera: Chrzaszcze = Coleoptera: Ryjkowcowate prócz ryjkowców - Curculionoidea prócz Curculionidae, Inst. Zoologiczny PAN, Katalog Fauny Polski $=$ Catalogus Faunae Poloniae, cz. 23, t. 18, PWN, Warszawa 1992, ss. 323, [1] [Zawiera Indeks nazw systematycznych w jęz. łac.].

24. Czyżma Jolanta, Roguszczak Elżbieta, Język łaciński. Podręcznik dla lektoratów uniwersyteckich, wyd 2, Wyd. UG, Gdańsk 1992, ss. 182 [Zawiera Stowniczek tacińsko-polski, Stownik polsko-łaciński].

25. Glosy i drobne teksty polskie do 1550 roku. Z inkunabulów archiwum archidiecezjalnego w Poznaniu, zebrał i wydał Julian Wojtkowski, objaśnienia językowe i indeks glos Zdzisława Krążyńska, PTPN, Wydz. Fil.-Filoz., Pr. Kom. Jęz. PTPN, t. 18, Wyd. PTPN, Poznań 1992, ss. 133, [2].

26. Jougan Alojzy, Stownik kościelny tacińsko-polski, [Wyd. 4], Wyd. Archidiecezji Warszawskiej, Warszawa 1992, ss. 746, [3] [Repr. wyd. 3 z 1958 r.].

27. Pałubicki Władysław, Słownik etnologiczno-religioznawczy, [wybór przysłów i sentencji łacińsko-polskich Róża Maria Pałubicka], Wyd. Uczeln. WSM, Gdynia 1992, ss. 175, [1] [Przysłowia i sentencje równol. w jęz. łac. i pol.]. 
28. Podlewski Jan Kazimierz, Chwalibogowska-Podlewska Alicja, Leki wspótczesnej terapii. Preparaty roślinne, varia, [oprac. haseł Joanna Dangel et al.], Fundacja Büchnera, Warszawa 1992 ss. XII, 108 [Zawiera Stownik tac.-pol. i pol.-łac. nazw wybranych roślin stosowanych $w$ medycynie oficjalnej i ludowej].

29. Stownik łaciny średniowiecznej $w$ Polsce $=$ Lexicon mediae et infimae Latinitatis Polonorum, t. 6, z. 7 (51), Ocula-Oxymel, Prac. Sł. Łac. Średniow. IJP PAN, [współpr. Aleksandra Baś-Kulbicka et al.], ZNO, Wrocław-Kraków [etc.] 1992, szp. 962-1202 [Addenda do tomów I-VI, [4] s.].

30. Stownik taciny średniowiecznej $w$ Polsce $=$ Lexikon mediae et infimae Latinitatis Polonorum, t. 7, z. 1 (52), Pabulamen-Patella, Prac. Sł. Łac. Średniow. IJP PAN, [współpr. Aleksandra Baś-Kulbicka et al.], IJP PAN, ZNO - PAN IJP, Wrocław-Kraków 1992, 160 łamów.

31. Wilczyński Stanisław, Zarych Teresa, Lectio latina dla klasy III liceum ogólnokształcacego. Cz. 1: Czytanki tacińskie, acute dicta, cantiunculae, czytanki polskie, słowniczek tacińsko-polski, wyd. 5, WSiP, Warszawa 1992, ss. 119, [1].

32. Wilczyński Stanisław, Zarych Teresa, Lectio latina dla klasy IV liceum ogólnokształcacego. Cz. 1: Czytanki łacińskie, cantiunculae, czytanki polskie, stowniczek tacińsko-polski, wyd. 5, WSiP, Warszawa 1992, ss. 135, [1].

33. Zając Maria, Index of general distribution maps. Vascular plants of Poland, Polish Botanical Studies. Guidebook Series 7, Polish Academy of Sciences, W. Szafer Institute of Botany, Kraków 1992, ss. 76 [Zawiera Indeks nazw roślin w jęz. łac.].

\section{3}

34. Aura dicta. Złote słowa. Stynne tacińskie sentencje, przysłowia i powiedzenia, [zebr. i oprac.] Stanisław Kalinkowski, [il. Paweł Szarlota], Veda, cop., Warszawa 1993, ss. 185.

35. Burakowski Bolesław, Mroczkowski Maciej, Stefańska Janina, Chrzaszcze = Coleoptera: Ryjkowce - Curculionidae, Cz. 1, Inst. Zoologiczny PAN, Kata$\log$ Fauny Polski $=$ Catalogus Faunae Poloniae, cz. 23, t. 19, PWN, Warszawa 1993, ss. 304, [1] [Zawiera Indeks nazw systematycznych w jęz. tac.].

36. Jurewicz Oktawiusz, Winniczuk Lidia, Żuławska Janina, Język łaciński. Podręcznik dla lektoratów szkół wyższych 1, wyd. 15, Wyd. Nauk. PWN, Warszawa 1993, ss. 263, [1] [Zawiera Stownik i skorowidz gramatyczny (tj. Stownik tacińsko-polski, Stownik imion własnych, Stownik terminów gramatycznych)].

37. Jurewicz Oktawiusz, Winniczuk Lidia, Żuławska Janina, Język łaciński. Podręcznik dla lektoratów szkót wyższych 2, wyd. 15, Wyd. Nauk. PWN, 
Warszawa 1993, ss. [257]-645, [1] [Zawiera Słownik i skorowidz gramatyczny (tj. Słownik łacińsko-polski, Stownik imion własnych, Słownik terminów gramatycznych)].

38. Łętowska Ewa, Podstawy prawa cywilnego, Wyd. Ecostar, Warszawa 1993, ss. 249, [1] [Zawiera Słownik terminów łacińskich].

39. Pieńkos Jerzy, Słownik łacińsko-polski. Łacina $w$ nauce i kulturze. Terminologia od starożytności do czasów nowożytnych. Nauki humanistyczne i społeczne. Prawo rzymskie i kanoniczne. Teologiczne słownictwo kościelne. Paremie prawnicze, sentencje, maksymy, aforyzmy, Wyd. Prawnicze, Warszawa 1993, ss. 445, [2].

40. Pieńkos Jerzy, Słownik łacińsko-polski. Prawo rzymskie i kanoniczne, teologiczne słownictwo kościelne, nauki humanistyczne i społeczne, zwroty $i$ wyrażenia używane $w$ nauce $i$ kulturze, sentencje, maksymy, aforyzmy, paremie, Wyd. Prawnicze, Warszawa 1993, ss. 445, [2].

41. Przystowie prawde ci powie. Przysłowia i cytaty. Antologia od A do Z, wybór i oprac. Jadwiga Pyczewska-Pilarek, Akapit Press, Łódź 1993, ss. 146.

42. Rezter Jan, Język łaciński dla prawników, wyd. 6, PWN, Warszawa 1993, ss. 284, [2] [Zawiera Stownik].

43. Stownik łaciny średniowiecznej w Polsce = Lexikon mediae et infimae Latinitatis Polonorum, t. 7, z. 2 (53), Patellator-Perdecet, PAN, Prac. Sł. Łac. Średniow., [współpr. Aleksandra Baś-Kulbicka et al.], IJP PAN, ZNO - IJP PAN, Wrocław-Kraków 1993, łamy 161-320.

44. Słownik łaciny średniowiecznej w Polsce = Lexikon mediae et infimae Latinitatis Polonorum, t. 7, z. 3 (54), Perdecet-Persuadeo, [współpr. Aleksandra Baś-Kulbika et al.], IJP PAN Kraków, Wyd. IJP PAN - ZNO [Wrocław] 1993, łamy 321-480.

\section{4}

45. Aurea dicta = Złote słowa. Stynne łacińskie sentencje, przysłowia i powiedzenia, oprac. Stanisław Kalinkowski, Veda, cop., Warszawa 1994, ss. 245, [1].

46. Chomoncik Marian, Język łaciński dla studentów medycyny, cz. 5: Słownik dydaktyczny polsko-łaciński, AM, Białystok 1994, ss. [4], 340, 18.

47. Czyżma Jolanta, Roguszczak Elżbieta, Język łaciński. Podręcznik dla lektoratów uniwersyteckich, wyd 3, Wyd. UG, Gdańsk 1994, ss. 222 [Zawiera Słowniczek łacińsko-polski, s. 145-199, Słownik polsko-łaciński, s. 201222].

48. Gronau Jerzy, Polsko-łaciński i łacińsko-polski słownik popularnych nazw ryb. Z przyporzadkowaniem poprzez kod do rodzin ryb wraz z uproszczona systematyką ryb, Wyd. „Księgarni Akademickiej” nr 12, Księg. Akad., Kraków 1994, ss. 227 [Tyt. okł. Słownik nazw ryb]. 
49. Jurewicz Oktawiusz, Winniczuk Lidia, Żuławska Janina, Język łaciński. Podręcznik dla lektoratów szkót wyższych 1, wyd. 16, Wyd. Nauk. PWN, Warszawa 1994, ss. 263, [1] [Zawiera Stownik i skorowidz gramatyczny (tj. Słownik łacińsko-polski, Słownik imion własnych, Słownik terminów gramatycznych)].

50. Jurewicz Oktawiusz, Winniczuk Lidia, Żuławska Janina, Język łaciński. Podręcznik dla lektoratów szkół wyższych, wyd. 16, Wyd. Nauk. PWN, Warszawa 1994, ss. 645, [1] [Zawiera Stownik i skorowidz gramatyczny (tj. Słownik łacińsko-polski, Słownik imion własnych, Słownik terminów gramatycznych)].

51. Kreyser Krystyna, Discipulus veterinarius, Wyd. SGGW, Warszawa 1994, ss. $200+C ́$ wiczenia językowe + Słownik łacińsko-polski, ss. 52.

52. Kubasiewicz Marian, Słownik terminologiczny z zakresu teratologii bydła, Wyd. Brasika, Szczecin 1994, ss. 243.

53. Mały słownik polsko-łaciński, red. nauk. Lidia Winniczuk, [oprac. Karolina Holzman et al.], Wyd. Nauk. PWN, Warszawa 1994, ss. 672.

54. Rezter Jan, Język łaciński dla prawników, wyd. 7, PWN, Warszawa 1994, ss. 284, [2] [Zawiera Stownik].

55. Rosławski Adam, Łacińsko-polskie nazewnictwo w rehabilitacji medycznej, [wyd. 1], Wyd. AWF, Wrocław 1994, ss. 43, [1].

56. Słownik łaciny średniowiecznej w Polsce = Lexikon mediae et infimae Latinitatis Polonorum, t. 7, z. 4 (55), Persuasibilis-Plaga, [współpr. Aleksandra Baś-Kulbicka et al.], IJP PAN [Prac. Sł. Łac. Średniow.], Wyd. IJP PAN, Kraków 1994, łamy 481-640.

57. Wilczyński Stanisław, Zarych Teresa, Lectio latina dla klasy II liceum ogólnokształcacego. Cz. 1: Czytanki łacińskie, cantiunculae, czytanki polskie, słowniczek łacińsko-polski, wyd. 7, WSiP, Warszawa 1994, ss. 111, [1].

58. Wilczyński Stanisław, Zarych Teresa, Lectio latina dla klasy III liceum ogólnokształcacego. Cz. 1: Czytanki łacińskie, acute dicta, cantiunculae, czytanki polskie, słowniczek łacińsko-polski, wyd. 6, WSiP, Warszawa 1994, ss. 119, [1].

59. Wilczyński Stanisław, Zarych Teresa, Lectio latina dla klasy IV liceum ogólnoksztatcacego. Cz. 1: Czytanki łacińskie, cantiunculae, czytanki polskie, słowniczek łacińsko-polski, wyd. 6, WSiP, Warszawa 1994, ss. 135, [1].

\section{5}

60. Burakowski Bolesław, Mroczkowski Maciej, Stefańska Janina, Chrząszcze = Coleoptera: Ryjkowce - Curculionidae, Cz. 2, Inst. Zoologiczny PAN, Kata$\log$ Fauny Polski = Catalogus Faunae Poloniae, cz. 23, t. 20, PWN, Warszawa 1995, ss. 310, [1] [Zawiera Indeks nazw systematycznych w jęz. łac.]. 
61. Chomoncik Marian, Słownik dydaktyczny polsko-łaciński, Język łaciński dla studentów medycyny, cz. 5, Wyd. Uczeln. AM, Białystok 1995, ss. [4], $340,18$.

62. Dictionary of animal production terminology: English, Polish, Russian, Latin = Słownik terminologii zootechnicznej [angielsko-polsko-rosyjsko-łaciński] = Zootehničeskij slovar', comp. by Polish Society of Animal Production, [ed. Barbara Reklewska et al.], Pol. Tow. Zootechniczne, Warszawa 1995, ss. [30], 669.

63. Jażdżewski Krzysztof, Konopacka Alicja, Pancerzowce prócz równonogów lądowych = Malacostraca prócz Oniscoidea, Katalog Fauny Polski = Catalogus Faunae Poloniae, cz. 13, t. 1, Dział Wydawnictw Muzeum i Inst. Zoologii PAN, Warszawa 1995, ss. 165 [Zawiera Indeks nazw systematycznych $w$ jęz. łac.].

64. Jurewicz Oktawiusz, Winniczuk Lidia, Żuławska Janina, Język łaciński. Podręcznik dla lektoratów szkót wyższych, wyd. 17, Wyd. Nauk. PWN, Warszawa 1995, ss. 650, [1] [Zawiera Stownik i skorowidz gramatyczny (tj. Słownik łacińsko-polski, Słownik imion własnych, Słownik terminów gramatycznych)].

65. Kamińska Maria, Cybulski Marek, Indeks łacińsko-polski do „Psałterza floriańskiego”, Komitet Językoznawstwa PAN, Wyd. Energeia, Warszawa 1995, ss. 96.

66. Kuryłowicz Marek, Słownik łacińskich terminów, zwrotów i sentencji prawniczych, Lubelskie Wydawnictwa Prawnicze, Lublin 1995, ss. 103.

67. Mały słownik polsko-łaciński, red. nauk. Lidia Winniczuk, [oprac. Karolina Holzman et al.], [wyd. 2], Wyd. Nauk. PWN, Warszawa 1995, ss. 672.

68. Pogorzelska-Stronczak Bogna, Paszek-Chromik Brygida, Zbiór wybranych określeń i rozpoznań używanych $w$ chirurgii stomatologicznej, Śląska AM, Katowice 1990, ss. 90.

69. Rezter Jan, Język łaciński dla prawników, wyd. 8, PWN, Warszawa 1995, ss. 284 [Zawiera Stownik].

70. Słownik łaciny średniowiecznej w Polsce = Lexicon mediae et infimae Latinitatis Polonorum, t. 7, z. 5 (56), Plaga-Possessionatus, [współpr. Aleksandra Baś-Kulbicka et al.] [Prac. Sł. Łac. Średniow.], IJP PAN, Kraków 1995, łamy 641-800.

71. Słownik łacińsko-polski. Wedtug słownika Hermana Gengego i Henryka Kopii, oprac. Kazimierz Kumaniecki, wyd. 19, PWN, Warszawa 1995, ss. VIII, 545 [2].

72. Świerczyńscy Dobrosława i Andrzej, Przysłowia w sześciu językach, Wyd. Nauk. PWN, Warszawa 1995, ss. 326 [Tekst równol. ang., franc., łac., niem., pol., ros.].

73. Wilczyński Stanisław, Zarych Teresa, Lectio latina dla klasy II liceum ogólnokształcacego. Cz. 1: Czytanki łacińskie, cantiunculae, czytanki polskie, słowniczek łacińsko-polski, wyd. 8, WSiP, Warszawa 1995, ss. 111, [1]. 
74. Wilczyński Stanisław, Zarych Teresa, Lectio latina dla klasy IV liceum ogólnokształcacego. Cz. 1: Czytanki tacińskie, cantiunculae, czytanki polskie, słowniczek tacińsko-polski, wyd. 7, WSiP, Warszawa 1995, ss. 135, [1].

75. Winiarczyk Marek, Sigla Latina in libris impressis occurrentia cum siglorum Graecorum appendice $=$ Skróty tacińskie $w$ książkach drukowanych $z$ dodaniem stów greckich, ed. 2 aucta et emendatior, Domus Editoria Universitatis Wratislaviensis, Wratislaviae 1995, ss. XII, 119, [3].

\section{6}

76. Czyżma Jolanta, Roguszczak Elżbieta, Język łaciński. Podręcznik dla lektoratów uniwersyteckich, wyd 4, Wyd. UG, Gdańsk 1996, ss. 223 [Zawiera Słowniczek łacińsko-polski, s. 145-199, Słownik polsko-łaciński, s. 201223].

77. Jarosz Jan, Gliński Zdzisław, Leksykon immunologii owadów, Wyd. Nauk. PWN, Warszawa 1996, ss. 165 [Hasła opatrzone są odpow. łac.].

78. Jurewicz Oktawiusz, Winniczuk Lidia, Żuławska Janina, Język łaciński. Podręcznik dla lektoratów szkót wyższych, wyd. 18, Wyd. Nauk. PWN, Warszawa 1996, ss. 650, [1] [Zawiera Stownik i skorowidz gramatyczny (tj. Stownik łacińsko-polski, Stownik imion własnych, Stownik terminów gramatycznych)].

79. Leksykon tacińsko-polski Jana Mączyńskiego. Wybór tekstów - opracowanie, wybór tekstów Władysław Kuraszkiewicz, oprac. Henryk Barycz, Władysław Kuraszkiewicz, Ignacy Lewandowski, Pr. Wydz. Hist.-Fil., Tow. Nauk. KUL 71, Wyd. Tow. Nauk. KUL, Lublin 1996, ss. 410.

80. Olszanowski Ziemowit, Rajski Aleksander, Wojciech Niedbała, Roztocze = Acari: Mechowce - Oribatida, Muzeum i Inst. Zoologii PAN, Katalog Fauny Polski $=$ Catalogus Faunae Poloniae, cz. 34, t. 9, Sorus, Poznań 1996, ss. 242, [2] [Zawiera Indeks nazw systematycznych w jęz. łac.].

81. Pieńkos Jerzy, Stownik łacińsko-polski. Łacina w nauce i kulturze. Terminologia od starożytności do czasów nowożytnych. Nauki humanistyczne $i$ społeczne. Prawo rzymskie i kanoniczne. Teologiczne słownictwo kościelne. Paremie prawnicze, sentencje, maksymy, aforyzmy, wyd. 2 rozsz. i popr., Wyd. Prawnicze, Warszawa 1996, ss. 477, [2].

82. Přibyl Jan, Ozdobne rośliny pokojowe, il. Zdenĕk Berger, [z jęz. franc. tłum. Elżbieta Traczewska-Zych], Leksykon Przyrody, Ofic. Wyd. Delta W-Z, Warszawa [1996], ss. 223, [1] [Zawiera Indeks nazw pol. i łac.].

83. Razowski Józef, Słownik morfologii owadów, Wyd. Nauk. PWN, Oddz., Warszawa-Kraków 1996, ss. VIII, [4], 430, [5] [Zawiera odpow. łac.].

84. Rejewski Marian, Pochodzenie łacińskich nazw roślin polskich. Przewodnik botaniczny, KiW, cop., Warszawa 1996, ss. 170, [2]. 
85. Sentencje biblioteczne Michała z Montaigne, oprac. Mieczysław Skinderowicz, Tow. Przyjaciół Książki, Oddz. Śląski, Katowice - Pszczyna 1996, ss. [20].

86. Stownik łaciny średniowiecznej $w$ Polsce $=$ Lexicon mediae et infimae Latinitatis Polonorum, t. 7, z. 6 (57), Possessionatus-praelargus, [współpr. Aleksandra Baś-Kulbicka et al.] [Prac. Sł. Łac. Średniow.], IJP PAN, Kraków 1996, łamy 801-960.

87. Słownik łacińsko-polski, Wyd. Tadeusza Radjusza Gutenberg-Print, Warszawa 1996, ss. [4], 980 [Wydawca nie zamieścił s. tyt. oryg., tyt. właściwy podstawy reprod.: Stownik łacińsko-polski do użytku szkót średnich, oprac. Juljan Dolnicki [et al.], pod kier. Bronisława Kruczkiewicza, wyd. 2, repr., oryg.: Książnica-Atlas, Lwów - Warszawa 1925].

88. Stownik łacińsko-polski wedtug słownika Hermana Mengego i Henryka Kopii, oprac. Kazimierz Kumaniecki, [wyd. 19], PWN, Warszawa 1996, ss. VIII, 545, [7].

89. Świerczyńscy Dobrosława i Andrzej, Przysłowia w sześciu językach, [il. Blanka Łątka], wyd. 2, Wyd. Nauk. PWN, Warszawa 1996, ss. 326, [2] [Tekst równol. ang., franc., łac., niem., pol., ros.].

90. Wilczyński Stanisław, Zarych Teresa, Lectio latina dla klasy II liceum ogólnokształcacego. Cz. 1: Czytanki tacińskie, cantiunculae, czytanki polskie, stowniczek tacińsko-polski, wyd. 9, WSiP, Warszawa 1996, ss. 111, [1].

91. Wilczyński Stanisław, Zarych Teresa, Rudimenta latinitatis, Cz. 1, Wyd. UWr, Wrocław 1996, ss. 109.

\section{7}

92. Aleksandrowicz Ryszard, Gielecki Jerzy, Gacek Witold, Stownik mian anatomicznych tacińsko-polsko-angielski $=$ Dictionary of anatomical terms Latin-Polish-English = Vocabularium terminorum anatomicorum, Wyd. Lek. PZWL, Warszawa 1997, ss. VII, [1], 446.

93. Aurea dicta $=$ Zlote stowa. Stynne tacińskie i greckie sentencje, przystowia oraz powiedzenia, 2, [zebr. i oprac.] Stanisław Kalinkowski, wyd. 1 [i.e.2], Veda, Warszawa 1997, ss. 303.

94. Belcarzowa Elżbieta, Glosy polskie w tacińskich kazaniach średniowiecznych, Cz. 3, Pr. IJP PAN 103, Wyd. Nauk. DWN, Kraków 1997, ss. 120, [1].

95. Czyżma Jolanta, Roguszczak Elżbieta, Język łaciński. Podręcznik dla lektoratów uniwersyteckich, wyd 4, dodr., Wyd. UG, Gdańsk 1997, ss. 223 [Zawiera Słowniczek łacińsko-polski, s. 145-199, Słownik polsko-łaciński, s. 201-223].

96. Dąbrowska Barbara, Podręczny słownik medyczny łacińsko-polski i polsko-łaciński, Wyd. Lek. PZWL, cop., Warszawa 1997, ss. 1110. 
97. Gielecki Jerzy, Gacek Witold, Wilczak Tomasz, Nomina. Multimedialny słownik anatomiczny tacińsko-polsko-angielski $=$ Multimedia anatomical dictionary, [dokument elektroniczny], Wyd. Lek. PZWL, cop., Warszawa 1997, wersja 2.0., 1 dysk opt. (CD-ROM) + broszura [Dokument towarzyszący: Jerzy Gielecki, Jarosław Wysocki, Historia polskiego mianownictwa anatomicznego, ss. 15].

98. Jędraszko Czesław, Łacina na co dzień, oprac. graf. Andrzej Strumiłło, wyd. 6 popr. i rozsz., Nasza Księgarnia, Warszawa 1997, ss. 411, [5] [Zawiera słownik].

99. Jurewicz Oktawiusz, Winniczuk Lidia, Żuławska Janina, Język łaciński. Podręcznik dla lektoratów szkót wyższych, wyd. 19, Wyd. Nauk. PWN, Warszawa 1997, ss. 650, [1] [Zawiera Stownik i skorowidz gramatyczny (tj. Słownik łacińsko-polski, Stownik imion własnych, Stownik terminów gramatycznych)].

100. Karwowska Krystyna, Podręczny słownik lekarski łacińsko-polski i polsko-taciński $=$ Vocabularium medicum manuale Latino-Polonum et Polono-Latinum, Wyd. Lek. PZWL, Warszawa 1997, ss. 1110.

101. Lubińska Bożena, Nowakowska Hanna, Skórcz Małgorzata, Mały słownik polsko-łaciński [wyrażenia i zwroty z języka literackiego, terminologia $z$ historii i prawa, terminologia z biologii i medycyny], Tow. Nauk. Organizacji i Kierownictwa „Dom Organizatora”, Toruń 1997, ss. 243.

102. Mały słownik polsko-łaciński, red. nauk. Lidia Winniczuk, [oprac. Karolina Holzman et al.], [wyd. 3], Wyd. Nauk. PWN, Warszawa 1997, ss. 672.

103. [Mymer Franciszek] Francisci Mymeri, Dictionarius trium linguarum: Latinae, Teutonicae et Polonicae [...], [Vietor, Cracoviae 1528] oprac. językoznawcze Włodzimierz Gruszczyński, oprac. polonistyczne Wacław Walecki, niem. tłum. posł. Małgorzata Trebisz i Michael Dewey, Biblioteka Tradycji Literackich, Collegium Columbinum, Kraków 1997, ss. [136], [52], 207, [36] [Na okł. i grzbiecie nazwy aut.: Mymerus, Murmellius. Karty zadrukowane dwustronnie; na podst. edycji unikatowego egz. słownika Franciszka Mymera z biblioteki Carolina Rediviva w Uppsali oraz przechowywanego tam również słownika Jana Murmeliusza; współwyd. z Dictionarius Ioannis Murmellii variarum rerum].

104. [Mymer Franciszek] Francisci Mymeri, Dictionarius trium linguarum, [oprac. językoznawcze Włodzimierz Gruszczyński, oprac. polonistyczne Wacław Walecki], Biblioteka Tradycji Literackich nr 13 A, 13 B, Collegium Columbinum, Kraków 1997, ss. 44, [5, 30, 32], 207 [Na okł. i grzbiecie nazwy aut.: Mymerus, Murmellius. Karty zadrukowane dwustronnie. Edycja na podst. egz. Stownika F. Mymera oraz Stownika J. Murmeliusza z Biblioteki Carolina Rediviva w Uppsali, oba bez ozn. sygnatury. Faks. oryg. oprac. w kier. przeciwstawnym; współwyd. z Dictionarius Ioannis Murmellii variarum rerum]. 
105. Przysłowia łacińskie, [wybór przysłów i sentencji dokonany przez Agatona Toczyłowskiego przy udziale Jana Kulasińskiego], Wyd. „Znicz”, [Szczecin] 1997, ss. 78.

106. Rezter Jan, Język łaciński dla prawników, wyd. 9, PWN, Warszawa 1997, ss. 284.

107. Rosławski Adam, Łacińsko-polskie nazewnictwo w rehabilitacji medycznej, wyd. 2, Wyd. AWF, Wrocław 1997, ss. 45.

108. Stownik łaciny średniowiecznej $w$ Polsce $=$ Lexicon mediae et infimae Latinitatis Polonorum, t. 7, z. 7 (58), Praelargus-Primatiatus, [współpr. Aleksandra Baś-Kulbicka et al.], IJP PAN, Kraków 1997, łamy 961-1120.

109. Stownik tacińsko-polski wedtug stownika Hermana Mengego i Henryka Kopii, oprac. Kazimierz Kumaniecki, [wyd. 21], PWN, Warszawa 1997, ss. VIII, 545, [7].

110. Stownik przystów, czyli 330 przystów i powiedzeń w ośmiu językach: polskim, francuskim, angielskim, hiszpańskim, tacińskim, niemieckim, rosyjskim i włoskim z ilustracjami, wybór przysłów Mirosława Słobodska [et al.], il. Elżbieta Szymanel-Krawczyńska, Lilianna Bogusławska, Harald G Dictionaries, Przeds. Wyd., cop. Warszawa 1997, ss. 755, [1].

111. Sondel Janusz, Stownik łacińsko-polski dla prawników i historyków, Universitas, cop., Kraków 1997, ss. XXX, [2], 1004, [3].

112. Thesaurus. Skarbiec tacińskich sentencji, przystów i powiedzeń w literaturze polskiej, zebr. i oprac. Mirosław Korolko, Wiedza Powszechna, Warszawa 1997, ss. XV, [1], 588, [2].

113. Urbanowicz Zygmunt, Stownik międzynarodowego mianownictwa anatomicznego, Wyd. UMCS, Lublin 1997, ss. 334.

114. Wilczyński Stanisław, Zarych Teresa, Lectio latina dla klasy II liceum ogólnoksztatcacego. Cz. 1: Czytanki tacińskie, cantiunculae, czytanki polskie, stowniczek łacińsko-polski, wyd. 10, WSiP, Warszawa 1997, ss. 111, [1].

115. Wykaz zwierzat Polski, t. 4, Cz. 1/31. Porifera -Symphyla $=$ Checklist of animals of Poland, vol. 4, Pt. 1-31. Porifera - Symphyla, red. Józef Razowski, [aut. Irena Bielańska-Grajner et al.], Inst. Systematyki i Ewolucji Zwierząt PAN, Kraków 1997, ss. 303 [Tekst pol., łac., ang.].

116. Wykaz zwierzat Polski, t. 5, Cz. 32/24. Hymenoptera - postowie $=$ Checklist of animals of Poland, vol. 5, Pt. 32/24. Hymenoptera-postscript, red. Józef Razowski, [aut. Zygmunt Bocheński et al.], Inst. Systematyki i Ewolucji Zwierząt PAN, Kraków 1997, ss. 260 [Tekst pol., łac., ang.].

\section{8}

117. Aleksandrowicz Ryszard, Gielecki Jerzy, Gacek Witold, Anatomia topograficzna. Przewodnik anatomiczny do ćwiczeń prosektoryjnych polsko-ła- 
ciński [Dla studentów wydziatów lekarskich i stomatologicznych akademii medycznych $]=$ Anatomia topographica . Enchiridion polono-latinum ad dissectiones corporis humani, Wyd. Lek. PZWL, Warszawa 1998, ss. X, [4], 486.

118. Andrzejuk Artur, Słownik terminów, przedm. opatrzył Mieczysław Gogacz, Suma teologiczna, św Tomasz z Akwinu, t. 35, Navo, Warszawa - Veritas, Londyn 1998, ss. 295, [1] [Poprz. tomy wyd. w Londynie].

119. Czyżma Jolanta, Roguszczak Elżbieta, Język łaciński. Podręcznik dla lektoratów uniwersyteckich, wyd 4, dodr., Wyd. UG, Gdańsk 1998, ss. 223 [Zawiera Słowniczek tacińsko-polski, s. 145-199, Słownik polsko-łaciński, s. 201-223].

120. Danka Jolanta, Kaźmierczak Małgorzata, Język taciński dla anglistów, [wyd. 1], Wyd. UŁ, Łódź 1998, ss. 199, [2] [Zawiera Stownik łacińskopolski, s. 189-199].

121. Entomologia stosowana, red. Barbara Wilkaniec, [zesp. aut.: Barbara Wilkaniec et al.], wyd. 2, Wyd. AR im. Augusta Cieszkowskiego, Poznań 1998, ss. 233 [Indeks w jęz. łac.].

122. Jurewicz Oktawiusz, Winniczuk Lidia, Żuławska Janina, Język łaciński. Podręcznik dla lektoratów szkót wyższych, wyd. 20, Wyd. Nauk. PWN, Warszawa 1998, ss. 650, [1] [Zawiera Stownik i skorowidz gramatyczny (tj. Stownik łacińsko-polski, Stownik imion własnych, Stownik terminów gramatycznych)].

123. Kaczyński Jerzy R., Florilegia czyli Łacina dla wszystkich, S-ka Wyd.-Księg., cop., Warszawa 1998, ss. 102 [Stanowi księgę cytatów].

124. Kuryłowicz Marek, Słownik terminów, zwrotów i sentencji prawniczych łacińskich oraz pochodzenia łacińskiego, Wyd. Zakamycze, Kraków 1998, ss. 154 [2].

125. Litewski Wiesław, Słownik encyklopedyczny prawa rzymskiego, Universitas, Kraków, cop., 1998, ss. VI, 322, [6] [Zawiera hasła w jęz. łac.].

126. Mały stownik polsko-łaciński, red. nauk. Lidia Winniczuk, [oprac. Karolina Holzman et al.], [wyd. 4], Wyd. Nauk. PWN, Warszawa 1998, ss. 672.

127. Mianownictwo histologiczne i cytofizjologiczne: polskie, angielskie, łacińskie [= Histological and cytophysiological nomenclature Polish, English, Latin = Nomenclatura histologica et cytophysiologica Polonica, Anglica, Latina], red. Wojciech Sawicki, oprac. Hieronim Bartel et al., Wyd. Lek. PZWL, Warszawa 1998, ss. IX, [1], 424.

128. Mironiuk Jolanta, Stowem do sukcesu. Stownik stynnych maksym, sentencji, przystów, powiedzeń, wyrazów, zwrotów i skrótów obcojęzycznych dla biznesmena, [WSM w Gdyni, Wydz. Admin.], Wyd. Uczeln. WSM, Gdynia 1998, ss. 116.

129. Rezter Jan, Język łaciński dla prawników, wyd. 10, PWN, Warszawa 1998, ss. 284 [Zawiera Stownik]. 
130. Rogowska Ewa, Kaszubskie nazwy roślin uprawnych, Wyd. UG, Warszawa 1998, ss. 194, [2] [Zawiera Słownik nazw; odpow. w jęz. pol., łac., niem.].

131. Ruszkowski Andrzej, Ruszkowski Jan, Słownik polskich nazw owadów. Cz. 1: Wersja polsko-łacińska i łacińsko-polska, Wyd. Inst. Sadownictwa i Kwiaciarstwa, Oddz. Pszczelnictwa, Puławy 1998, ss. 378.

132. Słownik łaciny średniowiecznej $w$ Polsce $=$ Lexicon mediae et infimae Latinitatis Polonorum, t. 7, z. 8 (59), Primaticus-Profundum, [współpr. Aleksandra Baś-Kulbicka et al.], IJP PAN, Kraków 1998, łamy 1121-1280.

133. Słownik łacińsko-polski, t. 1: A-C, wyd. 2 repr., red. Marian Plezia, [oprac. haseł Irena Kazik-Zawadzka et al.], Wyd. Nauk. PWN, Warszawa 1998, ss. LII, 827, [3] [Repr. słownika PWN wyd. w 1. 1957-1979].

134. Słownik łacińsko-polski, t. 2: $D-H$, wyd. 2 repr., red. Marian Plezia, [oprac. haseł Maria Chigerowa et al.], Wyd. Nauk. PWN, Warszawa 1998, ss. 744.

135. Słownik łacińsko-polski, t. 3: I-O, wyd. 2 repr., red. Marian Plezia, [oprac. haseł Maria Chigerowa et al.], Wyd. Nauk. PWN, Warszawa 1998, ss. VI, 751.

136. Świerczyńscy Dobrosława i Andrzej, Przysłowia w ośmiu językach, Wyd. Nauk. PWN, Warszawa 1998, ss. 436, [4] [Tekst równol. ang., franc., hiszp., łac., niem., pol., ros., wł.].

137. Wilczyński Stanisław, Zarych Teresa, Lectio Latina dla klasy II liceum ogólnoksztatcącego. Cz. 1: Czytanki: czytanki łacińskie, cantiunculae, czytanki polskie, słowniczek łacińsko-polski, wyd. 11, WSiP, Warszawa 1998, ss. 111, [1].

138. Wilczyński Stanisław, Zarych Teresa, Lectio latina dla klasy IV liceum ogólnokształcacego. Cz. 1: Czytanki łacińskie, cantiunculae, czytanki polskie, słowniczek łacińsko-polski, wyd. 8, WSiP, Warszawa 1998, ss. 135, [1].

139. Wilczyński Stanisław, Zarych Teresa, Rudimenta latinitatis, Cz. 1, wyd. 2 popr., Wyd. Uwr, Wrocław 1998, ss. 109.

\section{9}

140. Jurewicz Oktawiusz, Winniczuk Lidia, Żuławska Janina, Język łaciński. Podręcznik dla lektoratów szkół wyższych, wyd. 21, Wyd. Nauk. PWN, Warszawa 1999, ss. 650, [1] [Zawiera Stownik i skorowidz gramatyczny (tj. Słownik łacińsko-polski, Słownik imion własnych, Słownik terminów gramatycznych)].

141. Kolańczyk Kazimierz, Prawo rzymskie, zaktualizował Jan Kodrębski, wyd. 5 zm., 2 dodr., Wydawnictwa Prawnicze PWN, Warszawa 1999, ss. 521, [1] [Zawiera Słownik terminologii łacińskiej].

142. Kuryłowicz Marek, Słownik terminów, zwrotów i sentencji prawniczych łacińskich oraz pochodzenia łacińskiego, [wyd. 1], dodr. 1, Ministerstwo 
Sprawiedliwości, Departament Kadr i Szkolenia, Warszawa - Wyd. Zakamycze, Kraków 1999, ss. 154 [1].

143. Melech Wiktoria, Sentencje, cytaty, zwroty i przysłowia łacińskie, Rara Avis, Wyd. Alfa-Wero, Warszawa 1999, ss. 687, [4] [Tekst częśc. równol. łac., pol., ang., franc., niem., ros.].

144. Pieńkos Jerzy, Praecepta Iuris. Łacina dla prawników. Terminy, paremie, wyrażenia $w$ porządku systematycznym, Wyd. Muza, Warszawa 1999, ss. 238, [2].

145. Pieńkos Jerzy, Rzymska myśl prawnicza. Aforyzmy, przysłowia, Infor, cop., Warszawa 1999, ss. 111, [1].

146. Rezter Jan, Język łaciński dla prawników, wyd. 11, PWN, Warszawa 1999, ss. 284 [Zawiera Słownik].

147. Słownik Bartłomieja z Bydgoszczy. Wersja polsko-łacińska, Cz. 1: A-G, oprac. Elżbieta Kędelska, Irena Kwilecka, Arleta Łuczak, Inst. Slawistyki PAN, SOW, Warszawa 1999, ss. 214.

148. Słownik łaciny średniowiecznej $w$ Polsce = Lexicon mediae et infimae Latinitatis Polonorum, t. 7, z. 9 (60), Profundus-Protectio, [współpr. A. Baś-Kulbicka et al.], IJP PAN, Kraków 1999, łamy 1181-1440.

149. Słownik łacińsko-polski, t. 4: $P-R$, wyd. 2 repr., red. Marian Plezia, [oprac. haseł T. Górski et al.], Wyd. Nauk. PWN, Warszawa 1999, ss. 583, [1].

150. Słownik łacińsko-polski, t. 5: S-Z, wyd. 2 repr., red. Marian Plezia, [oprac. haseł Irmina Lechońska et al.], Wyd. Nauk. PWN, Warszawa 1999, ss. VIII, $673,[1]$.

151. Szumiłowicz Grzegorz, Mały słownik terminologii medycznej: język polski, język taciński, język ukraiński, Zapol, Szczecin 1999, ss. 279.

152. Wilczyński Stanisław, Zarych Teresa, Lectio latina dla klasy II liceum ogólnokształcacego. Cz. 1: Czytanki łacińskie, cantiunculae, czytanki polskie, słowniczek łacińsko-polski, wyd. 12, WSiP, Warszawa 1999, ss. 111, [1].

\section{0}

153. Bazyluk Władysław, Liana Anna, Prostoskrzydłe = Orthoptera, Katalog Fauny Polski $=$ Catalogus Faunae Poloniae, cz. 17, z. 2, Muzeum i Inst. Zoologii PAN, Warszawa 2000, ss. 156, [1] [Zawiera Indeks nazw systematycznych w jęz. łac.].

154. Czyżma Jolanta, Roguszczak Elżbieta, Język łaciński. Podręcznik dla lektoratów uniwersyteckich, wyd 4, dodr., Wyd. UG, Gdańsk 2000, ss. 223 [Zawiera Słowniczek łacińsko-polski, s. 145-199, Słownik polsko-łaciński, s. 201-223].

155. Jędraszko Czesław, Łacina na co dzień, oprac. graf. Andrzej Strumiłło, Nasza Księgarnia, Warszawa 2000, ss. 411, [5] [Zawiera słownik]. 
156. Jurewicz Oktawiusz, Winniczuk Lidia, Żuławska Janina, Język łaciński. Podręcznik dla lektoratów szkót wyższych, wyd. 22, Wyd. Nauk. PWN, Warszawa 2000, ss. 650, [1] [Zawiera Stownik i skorowidz gramatyczny (tj. Stownik łacińsko-polski, Stownik imion własnych, Stownik terminów gramatycznych)].

157. Kamińska Maria, Cybulski Marek, Kowalska Danuta, Stownik polsko-łaciński do średniowiecznych psałterzy polskich. Wyrazy autosemantyczne, Archidiecezjalne Wyd. Łódzkie, Łódź 2000, ss. 256.

158. [Liber scintillarum], Księga iskierek, t. 1: Defensor z Ligugé, przekł. i oprac. Radosław Wasiński, Biblioteka Ojców Kościoła nr 13, Warszawskie Tow. Teologiczne, cop., Kraków 2000, ss. 240 [Zawiera cytaty].

159. Madej Janusz A., Vademecum pathomorphologicum et Latino-Polonicum lexicon peculiarium, Wyd. AR we Wrocławiu, Wrocław 2000, ss. 241.

160. Mańkowski Jerzy przy współudziale Justyny Mańkowskiej, Praktyczny słownik łacińsko-polski, seria Słowniki, Prószyński i S-ka, Warszawa 2000, ss. 265, [4].

161. Pieńkos Jerzy, Rzymska myśl prawnicza. Aforyzmy, przystowia, Infor, cop., Warszawa 2000, ss. 111, [1].

162. Pogorzelska-Stronczak Bogna, Paszek-Chromik Brygida, Zbiór wybranych określeń i rozpoznań używanych $w$ chirurgii stomatologicznej, wyd. 2, Wyd. Śląska AM, cop., Katowice 2000, ss. 92.

163. Radziejewski Dariusz, Angielsko-łacińsko-polski stownik stynnych cytatów $z$ Biblii, Wyd. Altravox Press, cop., Włocławek 2000, ss. [4], 163.

164. Radziejewski Dariusz, Łacińsko-angielsko-polski słownik przystów, sentencji, zwrotów i wyrażeń, Wyd. Altravox Press, Włocławek 2000, ss. [4], 396.

165. Radzik Anna, Ze studiów nad frazeologia historyczna języka rosyjskiego. Frazeologizmy w niemiecko-łacińsko-rosyjskim Leksykonie Petersburskim z 1731 roku, Wyd. Nauk. AP w Krakowie, Kraków 2000, ss. 180 [Ok. 800 jedn. frazeol. jęz. ros. z odpow. niem. i pol., spis alfabet. haseł Leksykonu Petersburskiego].

166. Rezter Jan, Język łaciński dla prawników, wyd. 12, Wyd. Nauk. PWN, Warszawa 2000, ss. 284 [Zawiera Stownik].

167. Salamonowicz-Górska Iwona, Ćwiczenia z języka łacińskiego. Stowniczek polsko-łaciński, Wyd. UKSW, Warszawa 2000, ss. 118, [1].

168. Sentencje tacińskie na trzecie tysiaclecie, w oprac. Marka Dubińskiego, Astrum, Wrocław 2000, ss. 567 [Na okł. Bogactwo - przemijanie - los czlowieka - mitość - przyjaźń - wiedza - szczęście].

169. Stownik taciny średniowiecznej $w$ Polsce = Lexicon mediae et infimae Latinitatis Polonorum, t. 7, z. 10 (61), Protectio-quaero, [współpr. A. BaśKulbicka et al.] IJP PAN, Kraków 2000, łamy 1441-1600.

170. Stownik tacińsko-polski wedtug stownika Hermana Mengego i Henryka 
Kopii, oprac. Kazimierz Kumaniecki, wyd. 23, PWN, Warszawa 2000, ss. VIII, 464.

171. Słownik przystów, czyli 330 przystów i powiedzeń w ośmiu językach: polskim, angielskim, francuskim, hiszpańskim, łacińskim, niemieckim, rosyjskim i włoskim z ilustracjami, wybór przysłów Mirosława Słobodska [et al.], il. Elżbieta Szymanel-Krawczyńska, Lilianna Bogusławska, wyd. 2 popr., „Harald G”, cop., Warszawa 2000, ss. 755, [1] [Tyt. okł. Słownik przystów].

172. Świerczyńska Dobrosława, Świerczyński Andrzej, Patarlių žodynas 9 kalbom, lietuvyškosios dalies sudarytoja Rasa Kašetiene, Tyto alba, Vilnius 2000, ss. 412, [4] [Tyt. oryg. Słownik przysłów w ośmiu językach; tekst równol. ang., franc., hiszp., łac., niem., pol., ros., wł.].

173. Urbanowicz Zygmunt, Anatomia człowieka. Słownik encyklopedyczny, Wyd. Morpol, Lublin 2000, ss. 635 [Mianownictwo także w jęz. łac.].

174. Wilczyński Stanisław, Zarych Teresa, Lectio latina dla klasy II liceum ogólnokształcacego. Cz. 1: Czytanki łacińskie, cantiunculae, czytanki polskie, słowniczek łacińsko-polski, wyd. 13, WSiP, Warszawa [2000], ss. 111, [1].

175. Wilczyński Stanisław, Zarych Teresa, Lectio latina dla klasy IV liceum ogólnokształcacego. Cz. 1: Czytanki łacińskie, cantiunculae, czytanki polskie, słowniczek łacińsko-polski, wyd. 10, WSiP, Warszawa [2000], ss. 135, [1].

176. Witkowski Andrzej, Słownik skrótów transportowych $=$ Abkürzungsbuch für Verkehr = Dictionary of transport abbreviations $[A-Z]$ Pol. Wyd. Transportowe, Warszawa 2000, ss. VIII, 217, [3] [Wyjaśnienia skrótów w jęz.: ang., franc., hiszp., łac., niem., pol.].

\section{1}

177. Aurea dicta $=$ Złote słowa . Stynne łacińskie i greckie sentencje, przysłowia i powiedzenia, [zebr. i oprac.] Stanisław Kalinkowski, Veda, Warszawa 2001, ss. 332, [3] [rozsz. i uzup. wyd. tyt. z 1993 i 1994 r.].

178. Belcarzowa Elżbieta, Glosy polskie w łacińskich kazaniach średniowiecznych, cz. 4, Wyd. Nauk. DWN, Kraków 2001, ss. 234, [1].

179. Czyżma Jolanta, Roguszczak Elżbieta, Język łaciński. Podręcznik dla lektoratów uniwersyteckich, wyd 4, dodr., Wyd. UG, Gdańsk 2001, ss. 223 [Zawiera Słowniczek łacińsko-polski, s. 145-199, Słownik polsko-łaciński, s. 201-223].

180. Jurewicz Oktawiusz, Winniczuk Lidia, Żuławska Janina, Język łaciński. Podręcznik dla lektoratów szkól wyższych, wyd. 22, dodr., Wyd. Nauk. PWN, Warszawa 2001, ss. 650, [1] [Zawiera Słownik i skorowidz gramatyczny (tj. Słownik łacińsko-polski, Słownik imion własnych, Słownik terminów gramatycznych)]. 
181. Krysiak Kazimierz, Henryk Kobryń, Kobryńczuk Franciszek, Anatomia zwierzat, t. 1: Aparat ruchowy (ze skorowidzami nazw polskich $i$ nazw tacińskich), wyd. nowe (5 popr.), Wyd. Nauk. PWN, Warszawa 2001, ss. 513, [13].

182. Krysiak Kazimierz, Świeżyński Krzysztof, Anatomia zwierząt, t. 2: Narzqdy wewnętrzne i układ krążenia, wyd. nowe (3 popr.), Wyd. Nauk. PWN, Warszawa 2001, ss. 631, [1].

183. Kuryłowicz Marek, Słownik terminów, zwrotów i sentencji prawniczych łacińskich oraz pochodzenia łacińskiego, wyd. 2, Kantor Wyd. Zakamycze, Kraków 2001, ss. 154 [1].

184. Lepert Rajmund, Turyn Ewa, Stownik roślin i zwierzat. Nazewnictwo polskie, tacińskie, francuskie, [wyd. 1], Wiedza Powszechna, Warszawa 2001, ss. 530 [40 000 nazw roślin i zwierząt; indeksy: pol. - 14000 nazw, franc. - 14000 nazw, łac. -12000 terminów].

185. Łacińskie paremie w europejskiej kulturze prawnej i orzecznictwie sąów polskich, red. Witold Wołodkiewicz, Jerzy Krzynówka, Liber, Warszawa 2001, ss. 287.

186. Mały stownik łacińsko-polski, red. nauk. Józef Korpanty, [aut. Antoni Bobrowski et al.], Wyd. Szkolne PWN, Warszawa 2001, ss. XX, 656, [12].

187. Mańkowski Jerzy, przy współudziale Justyny Mańkowskiej, Praktyczny stownik łacińsko-polski, oprac. Prószyński i S-ka, Warszawa 2001, ss. 265, [4].

188. Pieńkos Jerzy, Rzymska myśl prawnicza. Aforyzmy, przysłowia, Infor, cop., Warszawa 2001, ss. 111, [1].

189. Pieńkos Jerzy, Stownik łacińsko-polski. Łacina w nauce i kulturze. Terminologia od starożytności do czasów nowożytnych. Nauki humanistyczne i spoleczne. Prawo rzymskie i kanoniczne. Teologiczne stownictwo kościelne. Paremie prawnicze, sentencje, maksymy, aforyzmy, Zakamycze, Kraków 2001, ss. 499, [2].

190. Rezter Jan, Język taciński dla prawników, wyd. 12, dodr., Wyd. Nauk. PWN, Warszawa 2001, ss. 284 [Zawiera Stownik].

191. Rosławski Adam, Lacińsko-polskie nazewnictwo w rehabilitacji medycznej, wyd. 3, Wyd. AWF, Wrocław 2001, ss. 45, [1].

192. Sentencje łacińskie na trzecie tysiaclecie, w oprac. Marka Dubińskiego, wyd. 1, dodr., Astrum, Wrocław 2001, ss. 567.

193. Stownik taciny średniowiecznej $w$ Polsce = Lexicon mediae et infimae Latinitatis Polonorum, t. 7, z. 11 (62): Quaero-quout, red. Krystyna Weyssenhoff-Brożkowa, [współpr. A. Baś-Kulbicka et al.], IJP PAN, Kraków 2001, szp. 1601-1800, [1] + Addenda do tomów 1-8, ss. [4].

194. Stownik łacińsko-polski, t. 1, $A-H$, red. nauk. Józef Korpanty, [zesp. aut. t. 2 Antoni Bobrowski et al.], Wyd. Szkolne PWN, Warszawa 2001, ss. XIII, [1], 846, [1]. 
195. Słownik łacińsko-polski wedtug słownika Hermana Mengego i Henryka Kopii, oprac. Kazimierz Kumaniecki, wyd. 24, PWN, Warszawa 2001, ss. VIII, 464.

196. Sondel Janusz, Słownik łacińsko-polski dla prawników i historyków, Universitas, cop., wyd. 2, Kraków 2001, ss. XXX, [2], 1004, [3].

197. Stanisław ze Skarbimierza, Mowy wybrane o mądrości = Sermones selecti de sapientia, oprac. Mirosław Korolko, [przekł. Bożena Chmielowska et al.], Tow. im. Stanisława ze Skarbimierza, Mądrość Polska, wyd. 2, Arcana, Kraków 2001, ss. 270, [1].

198. Świerczyńscy Dobrosława i Andrzej, Przysłowia $w$ ośmiu językach $=$ Dictionary of proverbs in eight languages, wyd. 2, Wyd. Nauk. PWN, Warszawa 2001, ss. 436, [4] [Tekst równol. ang., franc., hiszp., łac., niem., pol., ros., w1.].

199. Wilczyński Stanisław, Zarych Teresa, Lectio latina dla klasy II liceum ogólnokształcacego. Cz. 1: Czytanki łacińskie, cantiunculae, czytanki polskie, słowniczek łacińsko-polski, wyd. 14, WSiP, Warszawa [2001], ss. 111, [1].

\section{2}

200. Anatomiczne mianownictwo weterynaryjne. Łacińskie - polskie - angielskie, red. nauk. Zbigniew Milart, [oprac. Jerzy Kaleczyc et al.], [wyd. 1], Wyd. PWRiL, Warszawa 2002, ss. 356, [4].

201. Cappelli Adriano, Słownik łacińskich $i$ włoskich skrótów z okresu średniowiecza użwanych $w$ aktach, dokumentach, rekopisach i przedstawionych w ponad 14000 drzeworytach = Lexicon Abbreviaturarum = Wörterbuch Lateinischer und Italienischer Abkurzungen Wie sie in Urkunden und Holzschnitfen besonders des Mittelalters gebrauchlich sind, dargestellt in über 14000 Holzschnittzeichen, Danowski Press, Białogard 2002, ss. 23.

202. Czyżma Jolanta, Roguszczak Elżbieta, Język łaciński. Podręcznik dla lektoratów uniwersyteckich, wyd 4, dodr., Wyd. UG, Gdańsk 2002, ss. 223 [Zawiera Słowniczek łacińsko-polski, s. 145-199, Słownik polsko-łaciński, s. 201-223].

203. Daniluk Mirosław, Sigla. Zbiór skrótów nazw instytutów życia konsekrowanego, stowarzyszeń życia apostolskiego oraz innych instytucji z nimi zwiąanych, Wyd. KUL, Lublin 2002, ss. 255, [2].

204. Danka Jolanta, Kaźmierczak Małgorzata, Język łaciński dla anglistów, wyd. 2, Wyd. UŁ, Łódź 2002, ss. 199, [2] [Zawiera Stownik łacińsko-polski, s. 189-199].

205. Entomologia stosowana, red. Barbara Wilkaniec, [zesp. aut.: Barbara Wilkaniec et al.], wyd. 2, Wyd. AR im. Augusta Cieszkowskiego, Poznań 2002, ss. 246 [Indeks w jęz. łac.]. 
206. Fiałkowski Wojciech, Kittel Wojciech, Widelnice = Plecoptera, Katalog Fauny Polski $=$ Catalogus Faunae Poloniae, cz. 16, z. 3, Muzeum i Inst. Zoologii PAN, Warszawa 2002, ss. 72, [1] [Zawiera Indeks nazw systematycznych w jęz. tac.].

207. Gruchała Janusz S., Iucunda familia librorum. Humaniści renesansowi w świecie książki, Universitas, cop., Kraków 2002, ss. 325, [2] [Cytaty w jęz. ang., franc., łac., niem., wł. i odpow. pol.].

208. Jurewicz Oktawiusz, Winniczuk Lidia, Żuławska Janina, Język łaciński. Podręcznik dla lektoratów szkót wyższych, wyd. 23, Wyd. Nauk. PWN, Warszawa 2002, ss. 650, [1] [Zawiera Stownik].

209. Kościańska Beata, Strojnowski Stanisław, Stownik pojęć histologicznych polsko-łacińsko-angielski dla rejestrów nowotworowych, Centrum Onkologii, Inst. im. Marii Skłodowskiej-Curie, [International Agency for Research on Cancer (WHO), International Association of Cancer Registries], Warszawa 2002, ss. 357, [2] [W publikacji wykorzystano Międzynarodowa Statystyczną Klasyfikację Chorób i Problemów Zdrowotnych ICD-10].

210. Kuryłowicz Marek, Stownik terminów, zwrotów i sentencji prawniczych tacińskich oraz pochodzenia łacińskiego, Wyd. Zakamycze, Kraków 2002, ss. 154 [1].

211. Landowski Zbigniew, Woś Krystyna, Cytaty tacińskie na każda okazję. O człowieku i rzeczach ludzkich, Wyd. Literackie, Kraków 2002, ss. 190, [2].

212. Landowski Zbigniew, Woś Krystyna, Stownik cytatów tacińskich. Wyrażenia. Sentencje. Przystowia, Wyd. Literackie, Kraków 2002, ss. 754, [3].

213. Mądrość starożytnych. Wybrane sentencje tacińskie, tłum. na jęz. pol. Alfred J. Palla, Złote Myśli, Betezda, Rybnik 2002, ss. 242.

214. Mirek Zbigniew et al., Flowering plants and pteridophytes of Poland. A checklist $=$ Krytyczna lista roślin naczyniowych Polski, Biodiversity of Poland = Różnorodność biologiczna Polski, vol. 1, W. Szafer Institutr of Botany, Polish Academy of Sciences, Kraków 2002, ss. 442 [Lista gatunków równol. w jęz. łac., pol.].

215. Motyka-Zgłobicka Maria, Zgłobicki Wojciech, Atlas typów nomenklatorycznych rodziny Lecanoraceae $z$ herbarium $L B L-L=$ Atlas of nomenclature types of Lecanoraceae family, herbarium $L B L-L$, seria Porosty (Lichenes). Rodzina Lecanoraceae, J. Motyka, t. 5, Wyd. UMCS, Lublin 2002, ss. [86] [Indeks w jęz. łac.].

216. Przystowia tacińskie, [wybór przysłów i sentencji dokonany przez Agatona Toczyłowskiego przy udziale Jana Kulasińskiego], wyd. 2, Znicz, [Szczecin] 2002, ss. 127.

217. Salamonowicz-Górska Iwonna, Ćwiczenia z języka tacińskiego. Stowniczek polsko-łaciński, wyd. 2 uzup., Wyd. UKSW, Warszawa 2002, ss. 119.

218. Sentencje tacińskie, w oprac. Anny Tkaczyk, wyd. 1, dodr., seria Rozryw- 
ka, Wyd. Astrum, cop., Wrocław 2002, ss. 141 [Na okł.: Doskonate źródto cytatów na wszelkie okazje!].

219. Stownik łaciny średniowiecznej $w$ Polsce $=$ Lexicon mediae et infimae Latinitatis Polonorum, t. 8, z. 1 (63), Rabalipton-Reddo, [współpr. A. BaśKulbicka et al.], IJP PAN, Kraków 2002, łamów 160.

220. Stownik tacińsko-polski wedtug stownika Hermana Mengego i Henryka Kopii, oprac. Kazimierz Kumaniecki, wyd. 25, PWN, Warszawa 2002, ss. VIII, 464.

221. Szewc Andrzej, Leksykon tacińskich terminów, zwrotów i paremii prawniczych, Wyższa Szkoła Ekonomii i Administracji w Bytomiu, Bytom 2002, ss. 162.

222. Urbanowicz Zygmunt, Współczesne mianownictwo anatomiczne, Wyd. Czelej, cop., Lublin 2002, ss. [8], 535.

223. Wolfa-Heideggera atlas anatomii czlowieka. Indeksy, słowniki: łacińsko-polsko-angielski, polsko-łacińsko-angielski, angielsko-łacińsko-polski =Wolf-Heidegger's atlas of human anatomy. Indexes, dictionaries: Latin-Polish-English, Polish-Latin-English, English-Latin-Polish, [oprac. indeksów Agnieszka Andrzejczak i Aleksandra Kwolczak], konsult. nauk. Ryszard Aleksandrowicz, Wyd. Lek. PZWL, cop., Warszawa 2002, ss. 255 .

\section{3}

224. Anioł-Kwiatkowska Jadwiga, Wielojęzyczny słownik florystyczny polsko-łacińsko-angielsko-francusko-niemiecki, Acta Universitatis Wratislaviensis nr 2577, Wyd. Uwr, Wrocław 2003, ss. 691, [2] [Na okł.: Stownik zawiera ponad 6000 haset w językach: polskim, tacińskim, angielskim, francuskim i niemieckim].

225. Feneis Heinz, Ilustrowana anatomia człowieka. Mianownictwo międzynarodowe, [tłum. z jęz. niem. Renata Modrewska-Winowska i Jerzy Winowski], wyd. 4, zm. i uzup. Wolfgang Dauber, il. Gerhard Spitzer, red. nauk. thum. Ryszard Aleksandrowicz, Wyd. Lek. PZWL, cop., Warszawa 2003, ss. VII, [1], 576 [Uzup. z 5 wyd. ang. Aleksander Michajlik].

226. Gielecki St. Jerzy, Gajda Grzegorz, Ruszowski Wojciech, Multimedialny atlas anatomii polsko-łacińsko-angielski: kości, stawy i więzadła, [dokument elektroniczny], wyd. 1, Górnicki Wyd. Med., Wrocław 2003, 1 dysk opt. (CD-ROM).

227. Jędraszko Czesław, Łacina na co dzień, oprac. graf. Andrzej Strumiłło, Nasza Księgarnia, Warszawa 2003, ss. 441, [5] [Zawiera słownik].

228. Jurewicz Oktawiusz, Winniczuk Lidia, Żuławska Janina, Język łaciński. Podręcznik dla lektoratów szkót wyższych, wyd. 24, Wyd. Nauk. PWN, 
Warszawa 2003, ss. 650, [1] [Zawiera Stownik i skorowidz gramatyczny (tj. Stownik łacińsko-polski, Stownik imion własnych, Stownik terminów gramatycznych)].

229. Kuryłowicz Marek, Stownik terminów, zwrotów i sentencji prawniczych tacińskich oraz pochodzenia tacińskiego, wyd. 3, ed. 2003/2004, Wyd. Zakamycze, Kraków 2003, ss. 154 [1].

230. Landowski Zbigniew, Woś Krystyna, Stownik cytatów tacińskich. Wyrażenia. Sentencje. Przystowia, wyd. 1, dodr., Wyd. Literackie, Kraków 2003, ss. 754, [3].

231. Mały stownik tacińsko-polski, red. nauk. Józef Korpanty, [zesp. aut. Antoni Bobrowski et al.], wyd. 2, Wyd. Szkolne PWN, Warszawa 2003, ss. XX, 656, [12].

232. Mały słownik polsko-łaciński, red. nauk. Lidia Winniczuk, [oprac. Karolina Holzman et al.], wyd. 6, Wyd. Nauk. PWN, Warszawa 2003, ss. 672.

233. Mańkowski Jerzy, Praktyczny stownik łacińsko-polski, wyd. 2 rozsz., Prószyński i S-ka, Warszawa 2003, s. 408.

234. Palewicz Roman, Birds. English-Latin-Polish dictionary of species names = Ptaki. Angielsko-łacińsko-polski słownik nazw gatunkowych, nakł. aut., Gliwice 2003, ss. 279.

235. Pogorzelska-Stronczak Bogna, Paszek-Chromik Brygida, Zbiór wybranych określeń $i$ rozpoznań używanych $w$ chirurgii stomatologicznej, wyd. 3, Wyd. Czelej, Lublin 2003, ss. 92.

236. Rezter Jan, Język taciński dla prawników, wyd. 13, Wyd. Nauk. PWN, Warszawa 2003, ss. 284 [Zawiera Stownik].

237. Sentencje tacińskie, wybór i oprac. Jerzy Syjud, Videograf II, Katowice 2003, ss. 205, [3].

238. Stownik Barttomieja z Bydgoszczy, Cz. 2: H-M, oprac. Elżbieta Kędelska, Irena Kwilecka, Arleta Łuczak, Inst. Slawistyki PAN, SOW, Warszawa 2003, ss. 202.

239. Stownik botaniczny, [red. nauk. Alicja i Jerzy Szweykowscy, aut. not encyklopedycznych: Stanisław Balcerkiewicz et al.], wyd. 2 zm. i uzup., Wiedza Powszechna, Warszawa 2003, ss. 1136 [Zawiera Stownik nazw polskich i łacińskich].

240. Słownik łacińsko-polski, t. 2, I-Z, red. nauk. Józef Korpanty, [zesp. aut. t. 2 Dariusz Brodka et al.], Wyd. Szkolne PWN, Warszawa 2003, ss. VII, [1], 998, [2].

241. Sondel Janusz, Stownik łacińsko-polski dla prawników i historyków [dokument elektroniczny], Universitas, cop., Kraków 2003, 1 dysk opt. (CDROM).

242. Van den Berg Arnoud B., van der Have Tom, Keijl Guido, Ptaki Europy, red. całości Dominic Mitchell, il. Gerald Driessens [et al.], [przekł. Jan Czekaj], Elipsa, cop, Warszawa 2003, ss. 288 [Indeks nazw pol. i łac.]. 
243. Wolfa-Heideggera atlas anatomii człowieka. Indeksy, słowniki: łacińsko-polsko-angielski, polsko-łacińsko-angielski, angielsko-łacińsko-polski, [oprac. indeksów Agnieszka Andrzejczak i Aleksandra Kwolczak, konsult. nauk. Ryszard Aleksandrowicz, wyd. 1, dodr., Wyd. Lek. PZWL, cop., Warszawa 2003, ss. 255.

244. Wójciak Hanna, Porosty, mszaki, paprotniki, Flora Polski, Multico, Warszawa 2003, ss. 368 [Indeks nazw pol. i łac.].

\section{4}

245. Aurea dicta - (zlote słowa) dla ludzi władzy i polityki, wybrał i wstępem poprzedził Mirosław Krajewski, Verbum, Rypin 2004, ss. 229, [1] [Tyt. okł. Aurea dicta dla ludzi władzy i polityki].

246. Danka Jolanta, Kaźmierczak Małgorzata, Język łaciński dla anglistów, wyd. 3, Wyd. UŁ, Łódź 2004, ss. 199, [2] [Zawiera Stownik łacińsko-polski, s. 189-199].

247. Dicta. Zbiór łacińskich sentencji, przystów, zwrotów, powiedzeń z indeksem osobowym i tematycznym, zebrał, oprac. i zred. Czesław Michalunio, WSFP „Ignatianum”, Wyd. WAM, Kraków 2004, ss. 745, [4].

248. Górska Małgorzata, Walencja łacińskich rzeczowników odczasownikowych i odprzymiotnikowych na podstawie „Mów” Cycerona wraz ze stownikiem walencyjnym, Katedra Filologii Klasycznej (Łacińskiej) KUL, Wyd. KUL, Lublin 2004, ss. 366.

249. Index plantarum, red. nauk. Karol Węglarski, Hortus Botanicus Universitatis Posnaniensis, Bogucki Wyd. Nauk., Poznań 2004, ss. 383, [1] [Indeks łac.].

250. Jurewicz Oktawiusz, Winniczuk Lidia, Żuławska Janina, Język łaciński. Podręcznik dla lektoratów szkót wyższych, wyd. 25, Wyd. Nauk. PWN, Warszawa 2004, ss. 650 [Zawiera Stownik łacińsko-polski].

251. Korolko Mirosław, Stownik kultury śródziemnomorskiej w Polsce. Idee, pojęcia, miejsca. Z wypisami literackimi, Muza, Warszawa 2004, ss. 653, [3] [Zawiera terminy i cytaty łac. i ich pol. tłum.].

252. Mały stownik łacińsko-polski, red. nauk. Józef Korpanty, [zesp. aut. Antoni Bobrowski et al.], wyd. 3, Wyd, Szkol. PWN, Warszawa 2004, ss. XX, 656, [12].

253. Mały słownik polsko-łaciński, red. nauk. Lidia Winniczuk, [oprac. Karolina Holzman et al.], wyd. 7, Wyd. Nauk. PWN, Warszawa 2004, ss. 672.

254. Olech Maria, Lichens of the Tatra National Park. A checklist = Porosty Tatrzańskiego Parku Narodowego. Adnotowana lista taksonów, Biodiversity of the Tatra National Park = Bioróżnorodność Tatrzańskiego Parku Narodowego, vol. 2, W. Szafer Institute of Botany, Polish Academy of Sciences, Kraków 2004, ss. 137 [Indeks pol., łac.]. 
255. Rybicki Stanisław Romuald, Mądrość łaciny [Cz. 1], Biblioteka „Niedzieli”, t. 161, Tygodnik Katolicki „Niedziela”, Częstochowa 2004, ss. 400.

256. Rezter Jan, Język taciński dla prawników, wyd. 14, Wyd. Nauk. PWN, Warszawa 2004, ss. 284 [Zawiera Stownik, s. 227-281].

257. Sentencje łacińskie, w oprac. Marka Dubińskiego, wyd. 2, Astrum, Wrocław 2004, ss. 567, [1] [Wyd. 1: pt. Sentencje tacińskie na trzecie tysiaclecie, 2001].

258. Stownik taciny średniowiecznej $w$ Polsce $=$ Lexicon mediae et infimae Latinitatis Polonorum, t. 8, z. 2 (64), Reddo-Remuneratio, [współpr. A. Baś-Kulbicka et al.], Wyd. IJP PAN, Kraków 2004, łamy 162-310.

259. Stownik łaciny średniowiecznej $w$ Polsce $=$ Lexicon mediae et infimae Latinitatis Polonorum, t. 8, z. 3 (65), Remunerativus-Reticulum, [współpr. A. Baś-Kulbicka et al.], Wyd. IJP PAN, Kraków 2004, łamy 321-479.

260. Stownik międzynarodowego mianownictwa anatomicznego, t. 1: Macierz standaryzacyjna, Grupa Medyczna Medort, [Barbara Perner et al., red. Cezary Lipiński, Barbara Perner, Tomasz Perner], SO Medort, Łódź 2004, ss. 369, [7] [Tekst równol. ang., łac., pol.].

261. Stownik pochodzenia nazw i określeń medycznych. Antyczne i nowożytne dzieje chorób wich nazwach ukryte, zestawił i napisał Krzysztof Włodzimierz Zieliński, opieką filol. w zakresie hellenistyki i indoeuropeistyki objęła Hanna Zalewska-Jura, Wyd. $\alpha$-Medica Press, cop., Bielsko-Biała 2004, ss. 616.

262. Smagowicz Krzysztof, Mantichora. Etymologiczny słownik nazw zwierząt, Wyd. UJ, cop., Kraków 2004, ss. 367.

263. Świerczyńscy Dobrosława i Andrzej, Stownik przysłów w ośmiu językach: angielsko-francusko-hiszpańsko-wtosko-niemiecko-rosyjsko-łaciński $=$ Dictionary of proverbs in eight languages, Wyd. Nauk. PWN, Warszawa 2004, ss. 436, [4].

264. Thesaurus albo Skarbiec łacińskich sentencji, przystów i powiedzeń w literaturze polskiej, oprac. Mirosław Korolko, wyd. 2 popr. i uzup., red. nauk. tekstów łac. Jarosław Jakielaszek, Wiedza Powszechna, Warszawa 2004, ss. 1030, [1] [Wyd. 1 ogł. pt. Thesaurus].

265. „Thesaurus” Grzegorza Knapskiego, [dokument elektroniczny], reprodukcja cyfrowa, red. Włodzimierz Gruszczyński, Marek Kunicki-Goldfinger, indeksowanie stron „Thesaurusa” Marek Kunicki-Goldfinger, Aldona Przyborska-Szulc, Stare Druki Biblioteki Uniwersyteckiej w Warszawie 8, BUW, Sekcja Dokumentów Wtórnych, Warszawa 2004, 1 dysk opt. (CDROM) [Ze zbiorów: Biblioteki Uniwersyteckiej w Warszawie, IJP PAN, BN; Wprowadzenie: jak korzystać z reprodukcji cyfrowej „Thesaurusa”; Grzegorz Knapski, Thesaurus Polono-latino-graecus; Jadwiga Puzynina, „Thesaurus” Grzegorza Knapiusza; Podst. reprodukcji: Thesaurus Polono-latino-graecus seu Promptuarium Latinae et Grecae.... t. 1-2, ed. 2, Fr. Cezary Kraków 1943-1944; Podst. reprodukcji: Thesaurus Grzegorza 
Knapiusza. Siedemnastowieczny warsztat pracy nad językiem polskim, ZNO, Wrocław [etc.] 1961; tekst częśc. łac. i grec.].

266. Urbanowicz Zygmunt, Podręczny słownik międzynarodowego mianownictwa anatomicznego, Wyd. UMCS, Lublin 2004, ss. 324.

267. Wabik Ilona, Podręczny słowniczek polsko-łaciński, łacińsko-polski, [wybrane terminy medyczne i pojęcia zwiazane ze stużba zdrowia], Styl Granpok, Dąbrowa Górnicza [ca 2004], ss. 157.

\section{5}

268. Dąbrowska Barbara, Podręczny słownik medyczny tacińsko-polski i polsko-taciński $=$ Vocabularium medicum manuale Latino-Polonum et Polono-Latinum, wyd. 2 uakt., Wyd. Lek. PZWL, cop., Warszawa 2005, ss. 1101.

269. Dębiński Antoni, Rzymskie prawo prywatne. Kompendium, wyd. 2 popr., Lexis Nexis, Warszawa 2005, ss. 401 [Zawiera: Lacińskie sentencje prawnicze, s. 367-370, Indeks terminów i zwrotów tacińskich, s. 371-395].

270. Dicta. Zbiór tacińskich sentencji, przystów, zwrotów, powiedzeń z indeksem osobowym i tematycznym, zebr., oprac. i zred. Czesław Michalunio, WSFP „Ignatianum” - WAM, Kraków 2005, s. 745, [4].

271. Dziedzic Arkadiusz, Krupiński Jerzy, Terminologia łacińska w stomatologii zachowawczej, Katedra i Zakład Stomatologii Zachowawczej z Endodoncją Śląskiej AM, Wyd. Czelej, cop., Lublin 2005, ss. [6], 34.

272. Gielecki Jerzy, Grzegorz Gajda, Anna Żurada, Multimedialny atlas anatomii polsko-łacińsko-angielski: kości, stawy i więzadta, [dokument elektroniczny], wyd. 2 popr., Górnicki Wyd. Med., Wrocław 2005, 1 dysk opt. (CD-ROM).

273. Jankowiak Lucyna Agnieszka, Stownictwo medyczne Stefana Falimirza, t. 1: Poczatki renesansowej terminologii medycznej, Język na Pograniczach 31, Inst. Slawistyki PAN, Tow. Nauk. Warszawskie, SOW, Warszawa 2005 [Zawiera Aneks: Listy frekwencyjne, s. 319-456, m.in. Liste frekwencyjna zapożyczeń grecko-łacińskich i Listę frekwencyjna derywatów od grekolatynizmów].

274. Jurewicz Oktawiusz, Winniczuk Lidia, Żuławska Janina, Język łaciński. Podręcznik dla lektoratów szkót wyższych, wyd. 25, 1 dodr., Wyd. Nauk. PWN, Warszawa 2005, ss. 650, [1] [Zawiera Stownik i skorowidz gramatyczny (tj. Stownik tacińsko-polski, Stownik imion własnych, Stownik terminów gramatycznych)].

275. Karwowska Krystyna, Podręczny słownik lekarski łacińsko-polski i polsko-łaciński = Vocabularium medicum manuale Latino-Polonum et Polono-Latinum, wyd. 2 uakt., Wyd. Lek. PZWL, cop., Warszawa 2005, ss. 1110. 
276. Krajczyk Aleksandra, Kubica Dorota, Prima via. Wstępna nauka języka łacińskiego. Słownik, sentencje, Acta Universitatis Wratislaviensis 2807, Wyd. UWr. Wrocław 2005, ss. 56, [1].

277. Krysiak Kazimierz, Kobryń Henryk, Kobryńczuk Franciszek, Anatomia zwierzat, t. 1: Aparat ruchowy (ze skorowidzami nazw polskich i nazw łacińskich), wyd. nowe (5 popr.), 2 dodr., Wyd. Nauk. PWN, Warszawa 2005, ss. 513, [13].

278. Księga sentencji łacińskich (wybór), [wybór i red. Jolanta Muras], KDC, cop., Warszawa 2005, ss. 320.

279. Kubicka Emilia, Suwała Monika, Słownik łacińsko-polski, polsko-łaciński, Wyd. Buchmann, cop., [Warszawa] 2005, ss. 359 [Na okł.: Zawiera sentencje łacińskie, powiedzenia i przysłowia z literatury $i$ Biblii].

280. Kunachowicz Hanna et al., Tabele składu $i$ wartości odżywczej żywności = Food composition tables, Inst. Żywności i Żywienia w Warszawie, Wyd. Lek. PZWL, cop., Warszawa 2005, ss. 670, [1] [Tekst równol. pol., ang. Zawiera Stownik nazw roślin i zwierząt pol., łac., ang.].

281. Leksykon diagnoz medycznych polsko-łacińsko-angielski, red. Jan Zaniewski, aut. Bożena Bruska et al., konsult. nauk. Leszek Buzun et al., Poltext, Warszawa 2005, ss. 1095.

282. Lepert Rajmund, Turyn Ewa, Stownik polsko-łacińsko-francuski. Rośliny $i$ zwierzęta $=$ Dictionnaire polonais-latin-français. Végétaux at animaux, [wyd. 1], Wiedza Powszechna, Warszawa 2005, ss. 530 [Zawiera 39000 nazw; Indeks pol., łac., franc.].

283. Mały słownik łacińsko-polski, red. nauk. Józef Korpanty, [zesp. aut. Antoni Bobrowski et al.], wyd. 4, Wyd. Szkolne PWN, Warszawa 2005, ss. XX, 656.

284. Mały słownik łacińsko-polski, red. nauk. Józef Korpanty, [zesp. aut. Antoni Bobrowski et al.], wyd. 5, Wyd. Szkolne PWN, Warszawa 2005, ss. XX, 656.

285. Mały słownik polsko-łaciński, red. nauk. Lidia Winniczuk, [oprac. Karolina Holzman et al.], wyd. 8, Wyd. Nauk. PWN, Warszawa 2005, ss. 672.

286. Marcinkowski Jacek, Katalog bylin polecanych przez Związek Szkółkarzy Polskich, [aut. fot. Piotr Banaszczak et al.], Agencja Promocji Zieleni, Związek Szkółkarzy Polskich, Warszawa 2005, ss. 133 [Zawiera Słownik nazw rodzajowych polsko-łaciński i łacińsko-polski].

287. Rezter Jan, Język łaciński dla prawników, wyd. 14, dodr., Wyd. Nauk. PWN, Warszawa 2005, ss. 284 [Zawiera Słownik, s. 227-281].

288. Sentencje łacińskie, oprac. Marek Dubiński, Świat Książki - Bertelsmann Media, Warszawa 2005, ss. 567, [1].

289. Słownik Bartłomieja z Bydgoszczy. Wersja polsko-łacińska, Cz. 3: N-Pleć, oprac. Elżbieta Kędelska, Irena Kwilecka, Arleta Łuczak, Inst. Slawistyki PAN, SOW, Warszawa 2005, ss. 185. 
290. Słownik ryb i owoców morza = Словарь названий рыб и морепродуктов = Seafood dictionary, Biblioteczka „Magazynu Przemysłu Rybnego”, Wyd. WSFP Gdynia 2005, ss. $115+1$ dysk opt. (CD-ROM) [400 gat. ryb w jęz. rozszerz. UE oraz ros., łac. i norw.; indeks nazw pol. oraz 3-literowych kodów FAO; 18473 synonimów, 23 jęz.].

291. Sondel Janusz, Stownik łacińsko-polski dla prawników i historyków, wyd. 2, Universitas, Kraków 2005, ss. XXXI, [1], 1005.

\section{6}

292. Czekalski Mieczysław, Liściaste krzewy ozdobne o wszechstronnym zastosowaniu, 2, PWRiL, cop., Poznań 2006, ss. 200 [Na okł. podtyt.: Pnacza, krzewy zawsze zielone, rośliny mało znane $i$ w pojemnikach do dekoracji wnętrz; Zawiera Indeks nazw tac.].

293. Entomologia stosowana, red. Barbara Wilkaniec, [zesp. aut.: Barbara Wilkaniec et al.], wyd. 3 zm. i uzup., Wyd. AR im. Augusta Cieszkowskiego, Poznań 2006, ss. 257 [Indeks w jęz. łac.].

294. Fałtynowicz Wiesław, Kukwa Martin, Lista porostów i grzybów naporostowych Pomorza Gdańskiego = List of lichens and lichenicolous fungi of Gdańskie Pomerania, Acta Botanica Cassubica. Monographiae, Katedra Taksonomii Roślin i Ochrony Przyrody UG. Gdańsk 2006, ss. 98 [Tekst w jęz. pol., ang., łac.].

295. Haberer Martin, Rośliny pokojowe. Atlas kieszonkowy. 350 roślin do pokoju i ogrodu zimowego, [z niem. przeł. Krystyna Mazur], Ofic. Wyd. Delta W-Z, Warszawa [ca 2006], ss. 192 [Zawiera Skorowidz pol. i łac. nazw roślin].

296. Jankowiak Lucyna Agnieszka, Słownictwo medyczne Stefana Falimirza, t. 2: Słownik, Język na Pograniczach 31, Inst. Slawistyki PAN, Tow. Nauk. Warszawskie, SOW, Warszawa 2006, ss. 708.

297. Jurewicz Oktawiusz, Winniczuk Lidia, Żuławska Janina, Język łaciński. Podręcznik dla lektoratów szkół wyższych, wyd. 25, 2 dodr., Wyd. Nauk. PWN, Warszawa 2006, ss. 650, [1] [Zawiera Stownik i skorowidz gramatyczny (tj. Słownik łacińsko-polski, Słownik imion własnych, Słownik terminów gramatycznych)].

298. Krajczyk Aleksandra, Kubica Dorota, Prima via. Wstępna nauka języka łacińskiego. Słownik, sentencje, Acta Universitatis Wratislaviensis 2901, wyd. 2 popr., Wyd. UWr, Wrocław 2006, ss. 56, [1].

299. Maciejewski Ryszard, Drop Andrzej, Atlas of Clinical and Radiological Anatomy, Wyd. Czelej, Lublin 2006, ss. 277 [Objaśnienia w jęz.: łac., pol., ang.].

300. Mały słownik polsko-łaciński, red. nauk. Lidia Winniczuk, [oprac. Karolina Holzman et al.], wyd. 9, Wyd. Nauk. PWN, Warszawa 2006, ss. 672. 
301. Rezter Jan, Język taciński dla prawników, wyd. 14, dodr. 2, Wyd. Nauk. PWN, Warszawa 2006, ss. 284 [Zawiera Stownik, s. 227-281].

302. Ruszkowski Andrzej, Ruszkowski Jan, Stownik polskich nazw owadów. Cz. 2: Chrzaszcze (Coleoptera), Wyd. Inst. Sadownictwa i Kwiaciarstwa w Skierniewicach, Oddz. Pszczelnictwa, cop., Puławy 2006, ss. 273 [Tekst równol. łac. i pol.].

303. Rybicki Stanisław Romuald, Mąrość łaciny [Cz. 2], Biblioteka „Niedzieli”, t. 187, Tygodnik Katolicki „Niedziela”, Częstochowa 2006, ss. 263.

304. Stownik taciny średniowiecznej $w$ Polsce $=$ Lexicon mediae et infimae latinitatis Polonorum, t. 8, z. 4 (66), Reticulum-sagitto, [współpr. A. Baś-Kulbicka et al.], Wyd. IJP PAN, Kraków 2006, łamy 482-639.

305. Stownik łacińsko-polski tematyczny: medycyna, farmacja i anatomia, Wyd. Literat, cop., Toruń 2006, ss. 118.

306. Sondel Janusz, Stownik łacińsko-polski dla prawników i historyków, Universitas, cop., Kraków 2006, ss. XXXI, [1], 1005, [3].

\section{7}

307. Atlas anatomiczny, [rys. Laura Kłopotowska et al.], wyd. 1, Wyd. Literat, Toruń [2007], ss. 197 [Słownik w jęz. pol., ang., łac.].

308. Atlas anatomiczny ze słownikiem polsko-łacińsko-angielsko-niemieckim, Wyd. Literat, Toruń 2007, ss. 215.

309. Burczak Krzysztof, Dębiński Antoni, Jońca Maciej, Lacińskie sentencje i powiedzenia prawnicze [Dla studentów prawa, aplikantów i praktyków], Wyd. C.H. Beck, Warszawa 2007, ss. XX, 306.

310. Dębiński Antoni, Rzymskie prawo prywatne. Kompendium, wyd. 3 popr., Lexis Nexis, Warszawa 2007, ss. 400 [Zawiera: Łacińskie sentencje prawnicze, s. 367-370, Indeks terminów i zwrotów tacińskich, s. 371 - 395].

311. Gielecki Jerzy, Żurada Anna, Gajda Grzegorz, Multimedialny atlas anatomii polsko-tacińsko-angielski, Cz. 1: Kości, stawy i więzadła, [dokument elektroniczny], wyd. 3, Górnicki Wyd. Med., Wrocław 2007, 1 dysk opt. (CD-ROM).

312. Mały stownik tacińsko-polski, red. nauk. Józef Korpanty, [zesp. aut. Antoni Bobrowski et al.], wyd. 6, Wyd. Szkol. PWN, Warszawa 2007, ss. XX, 656, [12].

313. Mały słownik polsko-łaciński, red. nauk. Lidia Winniczuk, [oprac. Karolina Holzman et al.], wyd. 10, Wyd. Nauk. PWN, Warszawa 2007, ss. 672.

314. Nawrot Jan, Stownik nazw owadów, [dokument elektroniczny], wyd V.2.0, Inst. Ochrony Roślin, cop., Poznan 2007, 1 dysk opt. (CD-ROM) [Nazwy i indeksy w 9 jęz.: ang., czes., franc., łac., niem., pol., ros., słowac., węg.]. 
315. Rezter Jan, Język taciński dla prawników, wyd. 14, dodr. 3, Wyd. Nauk. PWN, Warszawa 2007, ss. 284 [Zawiera Stownik, s. 227-281].

316. Stownik taciny średniowiecznej $w$ Polsce $=$ Lexicon mediae et infimae latinitatis Polonorum, t. 8, z. 5 (67), Sagitto-scriniolum, [współpr. A. Kulbicka et al.], Wyd. IJP PAN, Kraków 2007, łamy 641-800.

317. Stownik łacińsko-polski, t. 1: $A-C$, red. prof. Marian Plezia, [oprac. haseł Maria Chigerowa et al.], wyd. 2, repr., 1 dodr., Wyd. Nauk. PWN, Warszawa 2007, ss. LII, 827.

318. Stownik łacińsko-polski, t. 2: $D-H$, red. prof. Marian Plezia, [oprac. haseł Maria Chigerowa et al.], wyd. 2, repr., 1 dodr., Wyd. Nauk. PWN, Warszawa 2007, ss. 744.

319. Słownik łacińsko-polski, t. 3: $I-O$, red. prof. Marian Plezia, [oprac. haseł Maria Chigerowa et al.], wyd. 2, repr., 1 dodr., Wyd. Nauk. PWN, Warszawa 2007, ss. VI, 751.

320. Stownik łacińsko-polski, t. 4: $P-R$, red. prof. Marian Plezia, [oprac. haseł Tytus Górski et al.], wyd. 2, repr., 1 dodr., Wyd. Nauk. PWN, Warszawa 2007, ss. VIII, 673.

321. Stownik łacińsko-polski, t. 5: $S-Z$, red. prof. Marian Plezia, [oprac. haseł Irmina Lechońska et al.], wyd. 2, repr., 1 dodr., Wyd. Nauk. PWN, Warszawa 2007, ss. VIII, 673.

322. Św. Tomasz z Akwinu, Człowiek, Cz. 1, 1. 75-84 = Summa theologica, 1, Quaestio 75-84, przeł. i objaśn. zaopatrzył Pius Bełch, Suma teologiczna, św. Tomasz z Akwinu t. 6, repr., [S.I. - s.n., ca 2007], ss. 296, [6] [Zawiera Stowniczek tacińsko-polski].

\section{8}

323. [Barszczewski Lavon], Thesaurus alboruthenico-latino-europaeus $=$ Stownik białorusko-europejsko-łaciński, Kolegium Europy Wschodniej im. Jana Nowaka-Jeziorańskiego, Warszawa 2008, ss. 1040.

324. Danka Jolanta, Kaźmierczak Małgorzata, Język łaciński dla anglistów, wyd. 4, Wyd. UŁ, Łódź 2008 [Zawiera Słownik łacińsko-polski, s. 189-199].

325. Dębiński Antoni, Rzymskie prawo prywatne. Kompendium, wyd. 4 popr., Lexis Nexis, Warszawa 2008, ss. 401, [1] [Zawiera: Lacińskie sentencje prawnicze, Indeks terminów $i$ zwrotów tacińskich].

326. Dicta. Zbiór łacińskich sentencji, przystów, zwrotów i powiedzeń z indeksem osobowym i tematycznym, zebr. i oprac. i zred. Czesław Michalunio, WSFP „Ignatianum” - WAM, Kraków 2008, ss. 745, [4].

327. Dicta editio maior. Zbiór tacińskich sentencji, przystów, zwrotów i powiedzeń $z$ indeksem osobowym i tematycznym, zebr. i oprac. i zred. Czesław Michalunio, WAM, Kraków 2008, ss. 625, [6] [Tyt. okł. Dicta editio maior]. 
328. Engler Wioleta, Słownik nazw ulic Elblaga, [tłum. Magdalena Brzezińska], Stan na 31 grudnia 2006 r., Wyd. Uran, Elbląg 2008, ss. 151, [1] [Tekst częśc. pol. i przekład niem., częśc. tłumaczony z niem. i łac.].

329. Gawryś Wiesław, Stownik roślin zielnych. Łacińsko-polski, Officina Botanica, Kraków 2008, ss. 199.

330. Gielecki Jerzy, Polsko-łacińsko-angielski atlas neuroanatomii: ośrodkowy i obwodowy uktad nerwowy = The Brain Matters: English-Latin-Polish atlas of neuroanatomy, [dokument elektroniczny], Górnicki Wyd. Med., Wrocław 2008, 1 dysk opt. (CD-ROM).

331. Gronau Jerzy, Nazewnictwo współczesnych ryb całego świata zawarte w tomach 1-9, [Nazwy w siedmiu jęz. wraz z systematyką, uwzględnia: naukowe nazwy łac. (z synonimami) oraz występujące odpow. w jęz: pol., ang., franc., niem., hiszp., ros. (w transkrypcji i cyrylicą)], t. 1, [Odtworzenie poprzez skanowanie wyd. 1-tomowego z grudnia 1996], [Jerzy Gronau], Kraków 2008, ss. [2], 216.

332. Gronau Jerzy, Nazewnictwo wspótczesnych ryb całego świata zawarte w tomach 1-9, [Nazwy w siedmiu jęz. wraz z systematyką, uwzględnia: naukowe nazwy łac. (z synonimami) oraz występujące odpow. w jęz: pol., ang., franc., niem., hiszp., ros. (w transkrypcji i cyrylicą)], t. 2, [Odtworzenie poprzez skanowanie wyd. 1-tomowego z grudnia 1996], [Jerzy Gronau], Kraków 2008, ss. [2], 217-420.

333. Gronau Jerzy, Nazewnictwo współczesnych ryb catego świata zawarte w tomach 1-9, [Nazwy w siedmiu jęz. wraz z systematyką, uwzględnia: naukowe nazwy łac. (z synonimami) oraz występujące odpow. w jęz: pol., ang., franc., niem., hiszp., ros. (w transkrypcji i cyrylicą)], t. 3, [Odtworzenie poprzez skanowanie wyd. 1-tomowego z grudnia 1996], [Jerzy Gronau], Kraków 2008, ss. [2], 421-640.

334. Gronau Jerzy, Nazewnictwo współczesnych ryb całego świata zawarte $w$ tomach 1-9, [Nazwy w siedmiu jęz. wraz z systematyką, uwzględnia: naukowe nazwy łac. (z synonimami) oraz występujące odpow. w jęz: pol., ang., franc., niem., hiszp., ros. (w transkrypcji i cyrylicą)], t. 4, [Odtworzenie poprzez skanowanie wyd. 1-tomowego z grudnia 1996], [Jerzy Gronau], Kraków 2008, ss. [2], 641-844.

335. Gronau Jerzy, Nazewnictwo współczesnych ryb całego świata zawarte w tomach 1-9, [Nazwy w siedmiu jęz. wraz z systematyką, uwzględnia: naukowe nazwy łac. (z synonimami) oraz występujące odpow. w jęz: pol., ang., franc., niem., hiszp., ros. (w transkrypcji i cyrylicą)], t. 5, [Odtworzenie poprzez skanowanie wyd. 1-tomowego z grudnia 1996], [Jerzy Gronau], Kraków 2008, ss. [2], 845-1054.

336. Gronau Jerzy, Nazewnictwo współczesnych ryb całego świata zawarte w tomach 1-9, [Nazwy w siedmiu jęz. wraz z systematyką, uwzględnia: naukowe nazwy łac. (z synonimami) oraz występujące odpow. w jęz: pol., 
ang., franc., niem., hiszp., ros. (w transkrypcji i cyrylicą)], t. 6, [Odtworzenie poprzez skanowanie wyd. 1-tomowego z grudnia 1996], [Jerzy Gronau], Kraków 2008, ss. [2], 1055-1267.

337. Gronau Jerzy, Nazewnictwo współczesnych ryb catego świata zawarte w tomach 1-9, [Nazwy w siedmiu jęz. wraz z systematyką, uwzględnia: naukowe nazwy łac. (z synonimami) oraz występujące odpow. w jęz: pol., ang., franc., niem., hiszp., ros. (w transkrypcji i cyrylicą)], t. 7, [Odtworzenie poprzez skanowanie wyd. 1-tomowego z grudnia 1996], [Jerzy Gronau], Kraków 2008, ss. [3], 1268-1436.

338. Gronau Jerzy, Nazewnictwo wspótczesnych ryb catego świata zawarte w tomach 1-9, [Nazwy w siedmiu jęz. wraz z systematyką, uwzględnia: naukowe nazwy łac. (z synonimami) oraz występujące odpow. w jęz: pol., ang., franc., niem., hiszp., ros. (w transkrypcji i cyrylicą)], t. 8, [Odtworzenie poprzez skanowanie wyd. 1-tomowego z grudnia 1996], [Jerzy Gronau], Kraków 2008, ss. [2], 1437-1622.

339. Gronau Jerzy, Nazewnictwo wspótczesnych ryb całego świata zawarte $w$ tomach 1-9, [Nazwy w siedmiu jęz. wraz z systematyką, uwzględnia: naukowe nazwy łac. (z synonimami) oraz występujące odpow w jęz: pol., ang., franc., niem., hiszp., ros. (w transkrypcji i cyrylicą)], t. 9, [Odtworzenie poprzez skanowanie wyd. 1-tomowego z grudnia 1996], [Jerzy Gronau], Kraków 2008, ss. [2], 1623-1800.

340. Jurewicz Oktawiusz, Winniczuk Lidia, Żuławska Janina, Język łaciński. Podręcznik dla lektoratów szkót wyższych, wyd. 25, 3 dodr., Wyd. Nauk. PWN, Warszawa 2008, ss. 650, [1] [Zawiera Stownik i skorowidz gramatyczny (tj. Stownik łacińsko-polski, Stownik imion własnych, Stownik terminów gramatycznych)].

341. Haberer Martin, Wielki atlas roślin ogrodowych i pokojowych. 1200 roślin do ogrodu, na taras, balkon, do mieszkania. 1220 barwnych zdjęć, [z niem. przeł. Krystyna Mazur], Delta, Warszawa [2007], ss. 697 [Zawiera Skorowidz pol. i łac. nazw roślin].

342. Kochanowski Jan, Carmina Latina, Ps. 2: Index verborum et formarum = Poezja tacińska, Cz. 2: Indeks wyrazów i form, oprac. Zofia Głombiowska, przy współudziale Stefanii Głombiowskiej, Wyd. UG, Gdańsk - Sopot 2008, ss. 379, [1].

343. Krajczyk Aleksandra, Kubica Dorota, Prima via. Wstępna nauka języka tacińskiego. Stownik, sentencje, Acta Universitatis Wratislaviensis 2901, wyd. 3 popr., Wyd. UWr, Wrocław 2008, ss. 56, [1].

344. [Kubicka Emilia, Suwała Monika], Stownik łacińsko-polski, polsko-łaciński, Literat, Torun 2008, ss. 797 [Na okł.: Stownik łacińsko-polski tematyczny: medycyna, farmacja i anatomia, gramatyka języka łacińskiego, zbiór sentencji, przystów i popularnych powiedzeń łacińskich]. 
345. Kubicka Emilia, Suwała Monika, Słownik łacińsko-polski, polsko-łaciński, Wyd. Buchmann, cop., [Warszawa] 2008, ss. 797 [Na okł. + Słownik medyczny + Gramatyka].

346. Kuryłowicz Marek, Wiliński Adam, Rzymskie prawo prywatne. Zarys wykła$d u$, wyd. 4 popr., seria Akademicka, Ofic. A Wolters Kluwer business, Warszawa 2008, ss. 303, [1] [Zawiera łac. sentencje prawnicze, s. 283-285].

347. Landowski Zbigniew, Woś Krystyna, Słownik cytatów łacińskich. Wyrażenia, sentencje, przysłowia, Wyd. Literackie, Kraków 2008, ss. 754, [1].

348. Makowiecka Maria Matylda, Skibniewski Michał, Szara Tomasz, Słownik mian anatomicznych łacińsko-angielski. Do Atlasu anatomii topograficznej zwierzat domowych Petera Popeski, PWRiL, Warszawa 2008, ss. 42, [1].

349. Mały słownik łacińsko-polski, red. nauk. Józef Korpanty, [zesp. aut. Antoni Bobrowski et al.], wyd. 7, Wyd. Szkol. PWN, Warszawa 2008, ss. XX, 656, [12].

350. Mały słownik polsko-łaciński, red. nauk. Lidia Winniczuk, [oprac. Karolina Holzman et al.], wyd. 11, Wyd. Nauk. PWN, Warszawa [2008], ss. 672.

351. Mańkowski Jerzy, przy współpracy Justyny Mańkowskiej, Praktyczny słownik łacińsko-polski, wyd. 3 rozsz., Prószyński i S-ka, Warszawa 2008, s. 406, [1].

352. Nawrot Jan, Słownik nazw owadów, [Dla uczniów i studentów, prac. służby ochrony roślin, ttumaczy, entomologów profesjonalistów i amatorów], Inst. Ochrony Roślin-PIB, Poznań 2008, ss. 551, [17] [Nazwy i indeksy w 8 jęz.: łac., pol., ang., niem., franc., czes., słowac., ros.].

353. Nawrot Jan, Słownik nazw owadów, [Leksykon stanowi narzędzie pracy dla naukowców, bibliotekarzy, tlumaczy oraz pomoc naukowa dla studentów etnomologii], [dokument elektroniczny], Inst. Ochrony Roślin-PIB, Poznań 2008, 1 dysk opt. [Nazwy i indeksy w 8 jęz.: łac., pol., ang., niem., franc., czes., słowac., ros.].

354. Popesko Peter, Atlas anatomii topograficznej zwierzat domowych $w$ wersji łacińsko-polskiej oraz stownik wersja łacińsko-angielska, PWRiL, Warszawa 2008, ss. 610.

355. Słownik łaciny średniowiecznej $w$ Polsce = Lexicon mediae et infimae latinitatis Polonorum, t. 8, z. 6 (68), Scrinium-septimana, [współpr. A. Kulbicka et al.], Wyd. IJP PAN, Kraków 2008, łamy 801-960.

356. Słownik łacińsko-polski, polsko-łaciński 3 w 1. [Zawiera] Słownik medyczny. Gramatyka, pr. zbior., Buchmann, Warszawa 2008, ss. 797.

357. Świerczyński Andrzej, Świerczyńska Dobrosława, Slovník přisloví v deviti jazycích, české ekvivalenty Eva Mrhačová, Euromedia Group - Universum, cop., Praha 2008, ss. 303, [1] [Tekst równol. czes., ang., franc., hiszp., łac., niem., pol., ros., wł.; tyt. oryg. Słownik przysłów w ośmiu językach]. 
358. Więcaszek Barbara et al., Wielojęzyczny słownik nazw ryb ozdobnych. Nazewnictwo polskie, tacińskie, angielskie, niemieckie, hiszpańskie i rosyjskie, AR w Szczecinie, Wyd. Nauk. AR, Szczecin 2008, ss. 156 [1].

359. Wiśniowolski Mieczysław, Regulae iuris. Lacińska terminologia prawnicza. Wybór maksym i formuł tacińskich, Wyd. Lux et Lex, Białystok 2008, ss. $253,[1]$.

\section{9}

360. ABBYY Lingvo X3 Multilingual Version (154 stowniki), praca zbiorowa, Wyd. ABBYY, 2009, 1 x CD [Wersja zawiera słowniki w 12 jęz.: ang., niem., franc., wł., hiszp., ros., chiń., tur., ukr., łac.].

361. Atlas anatomiczny, [rys. Laura Kłopotowska et al.], wyd. 2 zm. i rozsz., Wyd. Literat, Toruń [2009], ss. 197 [Słownik w jęz. pol., ang., łac.].

362. Atlas anatomiczny ze słownikiem polsko-łacińsko-angielsko-niemieckim, pr. zbior., wyd. 2, Wyd. Literat, Warszawa 2009, ss. 200.

363. Entomologia stosowana, red. Barbara Wilkaniec, [zesp. aut.: Barbara Wilkaniec et al.], wyd. 4, Wyd. Uniwersytetu Przyrodniczego, Poznań 2009, ss. 257 [Indeks w jęz. łac.].

364. Kuklo Cezary, Demografia Rzeczypospolitej przedrozbiorowej, Inst. Historii PAN, Nauki Pomocnicze Historii. Seria Nowa, Wyd. DiG, Warszawa 2009, ss. 521, [6] [Zawiera Stownik tac.-pol., s. 479-496].

365. Mały stownik tacińsko-polski, red. nauk. Józef Korpanty, [aut. Antoni Bobrowski et al.], wyd. 8, Wyd. Szkol. PWN, Warszawa 2009, ss. XX, 656, [12].

366. Mały słownik polsko-łaciński, red. nauk. Lidia Winniczuk, [oprac. Karolina Holzman et al.], wyd. 12, Wyd. Nauk. PWN, Warszawa 2009, ss. 672.

367. Marcinkowki Jacek, Kosaćce, Królowe Ogrodów, Wyd. Działkowiec, Warszawa 2009, ss. 87 [Indeks nazw pol. i łac.].

368. Przybyłowicz Anna, Atlas płazów i gadów, seria Przydatny z Natury Rzeczy, Wyd. Pascal, Bielsko-Biała 2009, ss. 95 [Indeks pol. i łac.].

369. Stownik Bartlomieja z Bydgoszczy. Wersja polsko-łacińska, Cz. 4: PlemięPytlowany, oprac. Elżbieta Kędelska, Irena Kwilecka, Arleta Łuczak, Inst. Slawistyki PAN, Fundacja Slawistyczna, SOW, Warszawa 2009, ss. 187, VII.

370. Stownik taciny średniowiecznej $w$ Polsce $=$ Lexicon mediae et infimae latinitatis Polonorum, t. 8, z. 7 (69), Septimanalis-simpliciter, [współpr. A. Kulbicka et al.], Wyd. IJP PAN 2009, łamy 961-1120.

371. Sondel Janusz, Stownik tacińsko-polski dla prawników i historyków. Wydanie na CD, Universitas, Kraków 2009, ss. XXXI, [1], 1005 + dysk opt. (CD-ROM).

372. Wilczyński Stanisław, Zarych Teresa, Rudimenta latinitatis, Cz. 1, wyd. 2 popr., dodr., Wyd. UWr, Wrocław 2009, ss. 109. 
373. Zoologia, t. 1: Bezkręgowce (bez stawonogów), red. nauk. Czesław Błaszak, Wyd. Nauk. PWN, Warszawa 2009, ss. XIV, 801 [Zawiera indeks].

\section{0}

374. Atlas anatomiczny, [rys. Laura Kłopotowska et al.], wyd. 3, Wyd. Literat, Toruń [2010], ss. 197 [Słownik w jęz. pol., ang., łac.].

375. Czajkowska-Matosiuk Katarzyna, Aplikacje prawnicze w pytaniach i odpowiedziach, t. 2, wyd, 4, stan prawny 1 . stycznia 2010, Wyd. C.H. Beck, Warszawa 2010, ss. XIV, $1072+1$ dysk opt. (CD-ROM) [Na okł. Sentencje tacińskie na $C D]$.

376. Dajczak Wojciech, Giaro Tomasz, Longchamps de Bérier Franciszek, Prawo rzymskie [tablice chronologiczne, tacińskie maksymy prawnicze z komentarzem, dzieje prawa rzymskiego $w$ powiazaniu z rozwojem europejskiego prawa prywatnego], Trener Akademicki, Wyd. Szkol. PWN, Warszawa - Park Prawo, Bielsko-Biała 2010, ss. 198.

377. Dicta. Zbiór łacińskich sentencji, przystów, zwrotów i powiedzeń z indeksem osobowym i tematycznym, zebr., oprac. i zred. Czesław Michalunio, wyd. 2 uzup., WAM, Kraków 2010, ss. 723, [6].

378. Ellis Harold, Logan Bari M., Dixon Adrian K., Atlas anatomiczny przekrojów ciała człowieka, [tłum. Katarzyna Dzięcioł], Alfa-Medica Press, cop., Bielsko-Biała 2010, ss. XVII, [1], 269 [Zawiera Indeks nazw tac.].

379. Jurewicz Oktawiusz, Winniczuk Lidia, Żuławska Janina, Język łaciński. Podręcznik dla lektoratów szkót wyższych, wyd. 25, 4 dodr., Wyd. Nauk. PWN, Warszawa 2010, ss. 650, [1] [Zawiera Stownik i skorowidz gramatyczny (tj. Stownik tacińsko-polski, Stownik imion własnych, Stownik terminów gramatycznych)].

380. Kerckhoff Annette, Łacina w pigutce dla zawodów zwiazanych z medycyna, [tłum. Maciej Gajowski], Wyd. MedPharm, cop., Wrocław 2010, ss. 138 [Praca ma charakter słownikowy].

381. Kieszonkowa anatomia topograficzna. Kości, stawy, więzadła. Przewodnik polsko-łaciński [Dla studentów wydziałów lekarskiego i lekarsko-dentystycznego oraz studentów fizykoterapii], red. nauk. Jerzy St. Gielecki, [aut. Ryszard Aleksandrowicz, Jerzy St. Gielecki, Anna Żurada], Wyd. Lek. PZWL, cop., Warszawa 2010, ss. X, 191.

382. Krajczyk Aleksandra, Kubica Dorota, Prima via. Wstępna nauka języka tacińskiego. Stownik, sentencje, Acta Universitatis Wratislaviensis 2010, wyd. 3 popr., dodr., Wyd. UWr, Wrocław 2010, ss. 56, [1].

383. Krysiak Kazimierz, Henryk Kobryń, Kobryńczuk Franciszek, Anatomia zwierzat, t. 1: Aparat ruchowy (ze skorowidzami nazw polskich i nazw tacińskich), wyd. 5, dodr., Wyd. Nauk. PWN, Warszawa 2010, ss. 516. 
384. Landowski Zbigniew, Woś Krystyna, Słownik cytatów tacińskich. Wyrażenia, sentencje, przysłowia, Wyd. Literackie, Kraków 2010, ss. 754, [5].

385. Mały stownik tacińsko-polski, red. nauk. Józef Korpanty, [aut. Antoni Bobrowski et al.], wyd. 9, Wyd. Szkol. PWN, Warszawa 2010, ss. XX, 656, [12].

386. Mały stownik polsko-łaciński, red. nauk. Lidia Winniczuk, [oprac. Karolina Holzman et al.], wyd. 13, Wyd. Nauk. PWN, Warszawa 2010, ss. 672.

387. Mańkowski Jerzy, przy współpracy Justyny Mańkowskiej, Praktyczny słownik tacińsko-polski, wyd. 3 rozsz., dodr., Prószyński i S-ka, Warszawa 2010, s. 406, [1].

388. Milanowski Janusz, Turowski Krzysztof, Cichoż-Lach Halina, Encyklopedia dla pielęgniarek i położnych ze słownikiem polsko-łacińsko-angielskim, t. 1-3, PZWL, Warszawa 2010, ss. 1222.

389. Pieńkos Jerzy, Praecepta Iuris. Łacina dla prawników. Sentencje, paremie, wyrażenia łacińskie w układzie systematycznym i alfabetycznym, [red. Artur Sucki], Pol. Wyd. Prawnicze Iuris, Warszawa 2010, ss. 345, [1].

390. Sentencje łacińskie, wybór i oprac. Jerzy Syjud, wyd. 1 w tej ed., Videograf Edukacja, Katowice - Chorzów 2010, ss. 187, [4].

391. Stownik łaciny średniowiecznej w Polsce = Lexicon mediae et infimae latinitatis polonorum, t. 8, z. 8 (70), Simplicius-specificative, [aut. haseł Aleksandra Kulbicka et al.], Wyd. IJP PAN, Kraków 2010, łamy 1121-1280.

392. Stownik tacińsko-polski tematyczny. Medycyna, anatomia, farmacja, wyd. 2, Wyd. Literat, Toruń [ca 2010], ss. 118.

393. Św. Tomasz z Akwinu, O cnotach rozumu. Komentarz do VI ksieggi ,Etyki nikomachejskiej” Arystotelesa, przekł. i oprac. Michał Głowala [et al.], współpr. Michał Filip, wstęp Michał Głowala, Bibliotheca Studiorum Philosophicorum Wratislaviensium, Translationes 1, Ofic. Wyd. „Atut” - Wrocławskie Wyd. Oświatowe, Wrocław 2010, ss. 211, [1] [Zawiera: Stownik tacińsko-polski głównych terminów „Komentarza” i „przypisów”, Stownik grecko-łaciński głównych terminów VI księgi ,Etyki nikomachejskiej”, s. 193-207].

394. Węcowski Jan, Stownik skrótów tacińskich, Fan Media, Warszawa 2010, ss. 165.

\section{1}

395. Atlas anatomiczny ze słownikiem polsko-łacińsko-angielsko-niemieckim, pr. zbior., wyd. nowe uzup., Wyd. Literat, Warszawa 2011, ss. 200.

396. Dębiński Antoni, Rzymskie prawo prywatne. Kompendium, wyd. 5, Lexis Nexis Polska, Warszawa 2011, ss. 375, [1] [Zawiera: Lacińskie sentencje prawnicze, Indeks terminów i zwrotów tacińskich].

397. Jurewicz Oktawiusz, Winniczuk Lidia, Żuławska Janina, Język łaciński. Podręcznik dla lektoratów szkót wyższych, wyd. 25, 5 dodr., Wyd. Nauk. 
PWN, Warszawa 2011, ss. 650, [1] [Zawiera Stownik i skorowidz gramatyczny (tj. Stownik łacińsko-polski, Stownik imion własnych, Stownik terminów gramatycznych)].

398. Kopiński Krzysztof, Tandecki Janusz, Glosarium wyrazów i zwrotów ze średniowiecznych źródet pruskich [= Glossary of words and phrases from medieval Prussian sources], UMK w Toruniu, Fontes, Tow. Nauk. w Toruniu, 104, Wyd. Tow. Nauk., Toruń 2011, ss. XLIV, 416, [2] [Hasła w jęz. łac., niem., pol.].

399. Księga sentencji i przystów łacińskich, wybór i oprac. Leopold Czapiński, Bogusław Skowron, wyd. 1. w tej ed., Twoje Wyd., Warszawa 2011, ss. 222, [2].

400. Łacina na co dzień, wybór Bogusław Skowron, Twoje Wyd., Warszawa 2011, ss. 181, [3] [Zawiera aforyzmy łac., wyrażenia i zwroty].

401. Łosowska Anna, Pennae investivi Praemisliae. Notariusze kancelarii kościelnych, pisarze sąów oraz urzędów świeckich $w$ XV i na poczatku XVI, Archiwum Państwowe Przemyskie Tow. Archiwistyczne „Archiwariusz”, Przemyśl 2011, ss. 397.

402. Mały stownik tacińsko-polski, red. nauk. Józef Korpanty, [aut. Antoni Bobrowski et al.], wyd. 10, Wyd. Szkolne PWN, Warszawa 2011, ss. XX, 656, [12].

403. Zoologia, t. 2: Stawonogi, Cz. 1: Szczękoczułkopodobne, skorupiaki, red. nauk. Czesław Błaszak, Wyd. Nauk. PWN, Warszawa 2011, ss. XII, 407, [1] [Indeksy stawonogów w jęz. łac.].

\section{B.R.W.}

404. Thesavrvs Polonolatinograecvs Sev Promptvarivm Lingvae Latinae et Graecae in tres Tomos diuisum: Polonorum, Roxolanorum, Sclauonum, Boёmorum vsui accommodatum [...], [t. 1], Opera Gregorii Cnapii [...], Est vero haec Editio secunda Operis huius, ab Auctore recogniti \& cum mendis, quae plurima priori editioni irrepserant sublatis, correcti ac purgati [...]. Accessit Index Latinus in priori editione promissus, plenissimus \& huic posteriori editioni accommodatus, quem alteram operis partem Latinopolonicam iure voces. Tertia pars Adagia continebit, Typis \& Sumptu Francisci Caesarij, Cracoviæ 1643, ss. [10] k., 1465 [i.e. 1467, 1 cz.] s., $2^{\circ}$, [Dokument tekstowy dostępny w wersji elektronicznej: http://ebuw.uw.edu.pl/ dlibra/docmetadata].

405. Thesavri Polonolatinograeci Gregorii Cnapii [...] Tomvs [...], t. 2: Latinopolonicvs, Simul idem Index verborum primi Tomi, ab Auctore confectus \& secundae editioni correctae ac multum auctae, accommodatus [...], Editio Secunda correcta \& aucta, Sumptu \& Typis Francisci Caesarij, Cracoviae 1644, ss. [8] k., 840, 40 s., 4 , [Na s. przedtyt.: R. P. Gregorij Cnapij So- 
cietatis Iesv Thesavri Latinopolonici Tomvs II], [Dokument tekstowy dostępny w wersji elektronicznej: http://ebuw.uw.edu.pl/dlibra/docmetadata].

\section{WNIOSKI KOŃCOWE}

Przedstawiona powyżej lista słowników z językiem łacińskim wydaje się świadczyć o intensywnym rozwoju polskiej leksykografii przekładowej ostatniego trzydziestolecia. Ogólnie na przestrzeni lat 1990-2011 pojawiło się 405 tytułów (proporcje liczbowe polskich wydań słowników z językiem łacińskim ilustruje wykres 1), co daje niemal półtorakrotną przewagę liczbową w stosunku do edycji z poprzedniego ćwierćwiecza, tj. z lat 1964-1989. Okres ten został nazwany przez polskich lingwistów okresem komercjalizacji leksykografii ${ }^{2}$, co ma tylko częściowe, jak się wydaje, uzasadnienie: oprócz bogatej i zróżnicowanej oferty publikacji użytkowych o różnym stopniu ich wartości edukacyjnej licznie reprezentowane są prace leksykograficzne stricte naukowe i dokumentacyjne - 179 pozycji (tj. 44\%). Implikacją gwałtownych przemian, jakie miały miejsce na polskim rynku wydawniczym po 1990 roku, jest przeważająca liczba 226 (tj. 56\%) publikacji komercyjnych i użytkowych, takich jak dwu- i wielojęzyczne słowniki ogólne i terminologiczne, opracowania leksykograficzne o charakterze popularyzatorskim (m.in. zbiory łacińskich paremii). Nowości wydawnicze prezentuje 175 (tj. 43\%) pozycji słownikarskich, zaś 230 (tj. 57\%) prac to modyfikacje, uzupełnienia, edycje aktualizowane, przedruki i digitalizacje.

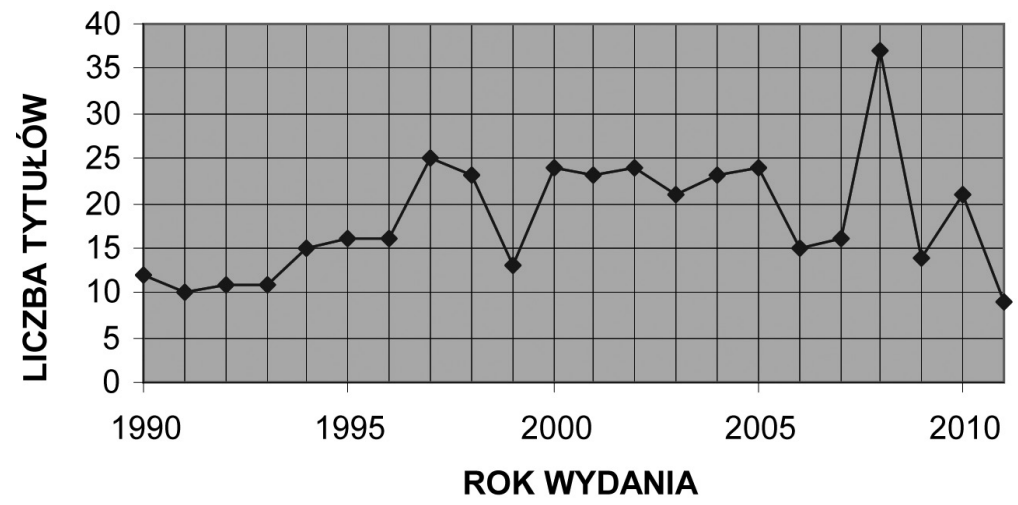

Wykres 1. Liczba tytułów opracowań leksykograficznych z językiem łacińskim $\mathrm{z}$ lat $1990-2011$

Obserwuje się spore zróżnicowanie tematyczno-problemowe w leksykograficzno-dokumentacyjnym opisie naukowym poszczególnych aspektów języka

${ }^{2}$ P. Żmigrodzki, Wprowadzenie do leksykografii polskiej, Katowice 2005, s. 153-155. 
łacińskiego - od słowników językowych ogólnych po aspektowe i wysoce specjalistyczne opracowania słownikarskie (m.in. Frazeologizmy w niemiecko-łacińsko-rosyjskim Leksykonie Petersburskim z 1731 Anny Radzik, Glosarium wyrazów i zwrotów ze średniowiecznych źródeł pruskich Kopińskiego i Tandeckiego, Sigla Latina in libris impressis occurrentia cum siglorum Graecorum appendice Winiarczyka etc.). Dostrzec można szereg naukowo ważkich i poznawczo interesujących, a przede wszystkim oryginalnych ujęć problematyki filologicznej: lingwistycznej, kulturowej, historycznej, etnologiczno-teologicznej etc. Słowniki filologiczne zmaterializowano w liczbie 203 (tj. 50,1\%) publikacji, z czego językowe ogólne stanowią 174 (tj. 43\%) tytułów, glosaria zaś to zaledwie 4 pozycje (tj. 0,9\%). Zauważa się istotny wzrost popularności wydań z zakresu paremiografii łacińsko-polskiej - odnotowano łącznie 83 (tj. 20,5\%) tytuły ksiąg oraz podtytuły zbiorów paremii i cytatów. Nadal znaczące miejsce w słownikarstwie polsko-łacińskim zajmuje terminografia - wyodrębniono 202 ( $\mathrm{tj}$. 49,8\%) prace w postaci słowników, leksykonów, encyklopedii, nomenklatorów i indeksów. Przeważa w niej leksyka z dziedziny medycyny, w tym weterynaryjnej - doliczono się 63 opracowań o tym profilu, które z kolei stanowią 31\% publikacji w zbiorze terminografii polsko-łacińskiej i 15,5\% całości zgromadzonego materiału bibliograficznego z językiem łacińskim. $Z$ zakresu zoologii wyekscerpowano 56 publikacji (tj. 28\% słowników terminologicznych z łaciną, co stanowi 14\% ogółu zebranych prac). Trzecie miejsce przypada słownikom z zakresu prawa $-46 \mathrm{pu}-$ blikacji (tj. 23\% zbioru terminografii i 11\% wszystkich zebranych), a dopiero na czwartym sytuują się prace leksykograficzne z dziedziny botaniki - 21 tytułów (tj. 10\% zebranych terminologicznych i 5\% całości zbioru). Spośród opracowań terminograficznych wyróżnić można również słowniki tematycznie związane $\mathrm{z}$ teologią i religią - 10 publikacji (tj. $5 \%$ terminograficznych i $2 \%$ wszystkich). Raczkująca jest leksykografia elektroniczna, utrwalająca ważkie z punktu widzenia spuścizny dorobku nauki polskiej dzieła słownikarskie (m.in. Tezaurus Knapiusza) w postaci dokumentu elektronicznego poprzez zapis na dysku optycznym oraz digitalizację dzieł dawnych w zasobach polskich bibliotek cyfrowych (odnotowano 14 dokumentów elektronicznych, tj. 3\%).

Wydaje się, że zarówno wydawcy, jak i autorzy słowników mają pełną świadomość znaczenia podstawowego narzędzia, jakim jest specjalistycznie ukierunkowany słownik przekładowy, pomocny w akwizycji języka łacińskiego, percepcji leksyki i frazeologii, przyswajaniu i normalizacji terminologii, a także w działalności filologicznej, naukowej i publiczno-społecznej. Z uwagi na przekładowy charakter słowniki pomagają w zgłębianiu wiedzy uczącym się języka łacińskiego, i to na wszystkich poziomach. Obfitość zgromadzonych danych bibliograficznych świadczy o produktywności słownikowej uczonych naszego kraju. Ułożona bibliografia odzwierciedla edytorską dynamikę i otwarcie na łacinę wydawnictw, agend i ośrodków naukowych, działających na terenie kraju. 
Zebranie tak obszernego materiału bibliograficznego stanowi niepodważalny dowód na to, iż, po pierwsze: język łaciński posiada wysoki status w świecie europejskiej nauki i kultury, po drugie: nie jest językiem martwym, bowiem trwale funkcjonuje w różnych rejestrach (głównie w tekstach pisanych): naukowych, literackich, historycznych, religijnych, prawnych, urzędowych etc. Łacina pozostaje wciąż znaczącym narzędziem w procesie zarządzania terminologią, swoistym lingua franca w kontaktach naukowych i kulturowych bez względu na fakt, iż w chwili obecnej w żywej tradycji ustnej jest dość mocno ograniczona. Słowniki, których komponent stanowi język łaciński, są swoistym wyznacznikiem intelektualnego i kulturowego poziomu naszego narodu.

\section{WYKAZ ZASTOSOWANYCH SKRÓTÓW:}

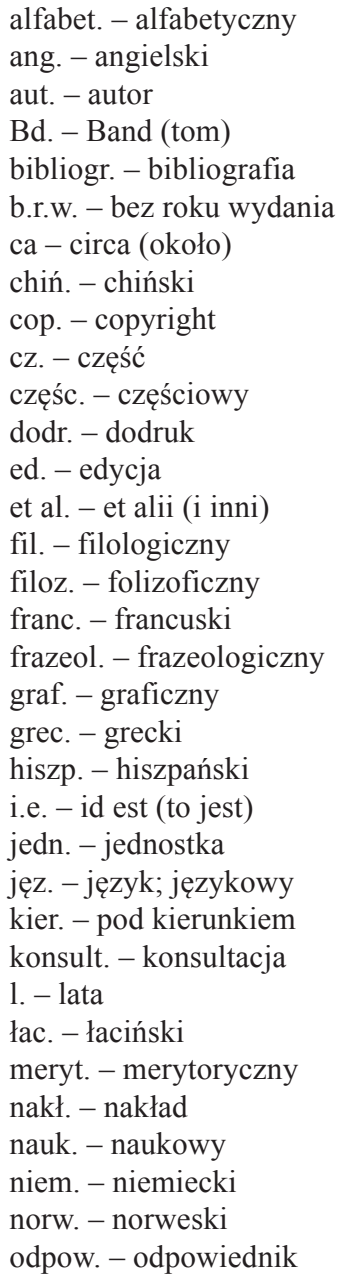

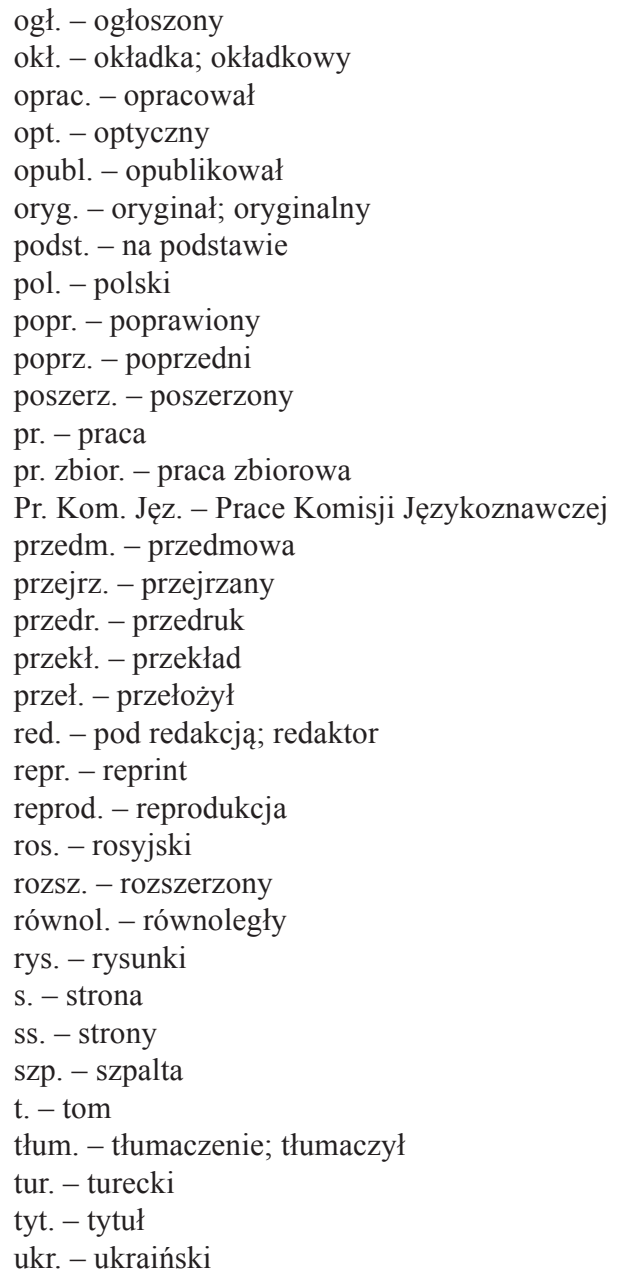


uzup. - uzupełniony; uzupełnienie

współpr. - współpraca

wł. - włoski

wyd. - wydanie

z. - zeszyt zebr. - zebrał

zesp. - zespół

zm. - zmieniony

zool. - zoologiczny

zred. - zredagował

\section{WYKAZ SKRÓTÓW NAZW INSTYTUCJI}

AM - Akademia Medyczna

AP - Akademia Pedagogiczna

AR - Akademia Rolnicza

ATK - Akademia Teologiczno-Katolicka

AWF - Akademia Wychowania Fizycznego

BUW - Biblioteka Uniwersytecka w Warsza-

wie

DWN - Drukarnia Wydawnictw Naukowych

IJP - Instytut Języka Polskiego

Inst. - Instytut

Inst. Zool. - Instytut Zoologiczny

Kom. - Komisja

Księg. Akad. - Księgarnia Akademicka

KUL - Katolicki Uniwersytet Ludowy

MPR - „Magazyn Przemysłu Rybnego”

Oddz. - Oddział

PAN - Polska Akademia Nauk

Pol. Tow. - Polskie Towarzystwo

Prac. Sł. Łac. Średniow. - Pracownia Słownika

Łaciny Średniowiecznej

PTPN - Poznańskie Towarzystwo Przyjaciół Nauk

PWN - Państwowe Wydawnictwo Naukowe

PWRiL - Państwowe Wydawnictwa Rolne i Leśne

PZWL -Państwowe Zakłady Wydawnictw Lekarskich

SGGW - Szkoła Główna Gospodarstwa Wiejskiego

SOW - Slawistyczny Ośrodek Wydawniczy

S-ka - Spółka
S-ka Wyd.-Księg. - Spółka Wydawniczo-Księgarska

TEPIS - Polskie Towarzystwo Tłumaczy Przysięgłych i Specjalistycznych

Tow. - Towarzystwo

Tow. Nauk. - Towarzystwo Naukowe

UE - Unia Europejska

UKSW - Uniwersytet Kardynała Stanisława Wyszyńskiego

UMCS - Uniwersytet im. Marii Curie-Skłodowskiej w Lublinie

UW - Uniwersytet Warszawski

UWr - Uniwersytet Wrocławski

WAiF - Wydawnictwa Artystyczne i Filmowe

WSFP - Wyższa Szkoła Filozoficzno-Pedagogiczna „Ignatianum”

WSiP - Wydawnictwa Szkolne i Pedagogiczne

WSM - Wyższa Szkoła Morska

WUW - Wydawnictwa Uniwersytetu Warszawskiego

Wyd. - Wydawnictwo

Wyd. Lek. - Wydawnictwo Lekarskie

Wyd. Med. - Wydawnictwo Medyczne

Wyd. Szkol. - Wydawnictwo Szkolne

Wyd. Uczeln. - Wydawnictwo Uczelniane

Wydz. - Wydział

Wydz. Fil.-Filoz. - Wydział Filologiczno-Filozoficzny

ZNO - Zakład Narodowy im. Ossolińskich

\section{ИЗ ПОЛЬСКОЙ ПЕРЕВОДНОЙ ЛЕКСИКОГРАФИИ. Ч. ІІ. БИБЛИОГРАФИЯ \\ СЛОВАРЕЙ С ЛАТИНСКИМ ЯЗЫКОМ ЗА ГГ. 1990-2011 В ХРОНОЛОГИЧЕСКОМ ПОРЯДКЕ}

Рез юм е

Настоящая статья представляет собой библиографический перечень 405 лексикографических работ с латинским языком, изданных в Польше в 1990-2011 гг., в эпоху т.н. ком- 
мерческой лексикографии. Главная цель статьи - раскрыть богатство польской переводной лексикографии с латинским языком. Дополнительно настоящий перечень регистрирует словари польских ученых, изданные за рубежом. Ядром подготовленного библиографического перечня являются переводные лексикографические работы (дву- и многоязычные): филологические, терминологические, документальные и энциклопедические. Библиографический список включает, в частности, указатели терминов с толкованиями, глоссарии, лексикографические дополнения, обратные указатели, собрания сокращений, антологии латинских паремий и цитат, а также одноязычные толковые словари и труды по электронной лексикографии. Материал к настоящей библиографии собран и каталогизирован на основе библиографических источников, научных трудов, подписных каталогов и каталогов польских научных библиотек.

Составление такого обширного библиографического перечня свидетельствует, несомненно, о том, что латинский язык принадлежит к группе престижных языков с высоким статусом в мире европейской науки и культуры. Латинский язык функционирует непрерывно в разных языковых стилях (главным образом в письменных текстах). Словари с латинским языком являются, несомненно, своеобразным детерминантом интеллектуального и культурного уровня народа. 